\title{
The Current State of Knowledge of Hepatic Ischemia-Reperfusion Injury Based on Its Study in Experimental Models
}

\author{
M. Mendes-Braz, ${ }^{1}$ M. Elias-Miró, ${ }^{2}$ M. B. Jiménez-Castro, ${ }^{2}$ A. Casillas-Ramírez, ${ }^{2}$ \\ F. S. Ramalho, ${ }^{1}$ and C. Peralta ${ }^{2,3}$ \\ ${ }^{1}$ Departamento de Patologia e Medicina Legal, Faculdade de Medicina, Universidade de Sao Paulo, \\ 14040-900 Ribeirão Preto, SP, Brazil \\ ${ }^{2}$ Institut d'lnvestigacions Biomèdiques August Pi i Sunyer (IDIBAPS), 08036 Barcelona, Spain \\ ${ }^{3}$ Centro de Investigación Biomédica en Red de Enfermedades Hepáticas y Digestivas, 08036 Barcelona, Spain
}

Correspondence should be addressed to C. Peralta, cperalta@clinic.ub.es

Received 1 December 2011; Accepted 23 February 2012

Academic Editor: Oreste Gualillo

Copyright () 2012 M. Mendes-Braz et al. This is an open access article distributed under the Creative Commons Attribution License, which permits unrestricted use, distribution, and reproduction in any medium, provided the original work is properly cited.

The present review focuses on the numerous experimental models used to study the complexity of hepatic ischemia/reperfusion $(\mathrm{I} / \mathrm{R})$ injury. Although experimental models of hepatic $\mathrm{I} / \mathrm{R}$ injury represent a compromise between the clinical reality and experimental simplification, the clinical transfer of experimental results is problematic because of anatomical and physiological differences and the inevitable simplification of experimental work. In this review, the strengths and limitations of the various models of hepatic I/R are discussed. Several strategies to protect the liver from I/R injury have been developed in animal models and, some of these, might find their way into clinical practice. We also attempt to highlight the fact that the mechanisms responsible for hepatic I/R injury depend on the experimental model used, and therefore the therapeutic strategies also differ according to the model used. Thus, the choice of model must therefore be adapted to the clinical question being answered.

\section{Introduction}

Ischemia-reperfusion (I/R) injury is a phenomenon in which cellular damage in a hypoxic organ is accentuated following the restoration of oxygen delivery [1-3]. In the liver, this form of injury was recognized as a clinically important pathological disorder by Toledo-Pereyra et al. in 1975 during studies of experimental liver transplantation (LT). However, it was not until the mid-1980s that the term reperfusion injury was generally used in the literature on LT [2]. I/R injury is an important cause of liver damage occurring during surgical procedures including hepatic resections and LT [4-6]. The shortage of organs has led centers to expand their criteria for the acceptance of marginal grafts that exhibit poor tolerance to I/R [7]. Some of these include the use of organs from older donors and grafts such as small-for-size or steatotic livers. However, I/R injury is the underlying cause of graft dysfunction in marginal organs [7]. Indeed, the use of steatotic livers for transplantation is associated with an increased risk of primary nonfunction or dysfunction after surgery [8]. In addition, the occurrence of postoperative liver failure after hepatic resection in a steatotic liver exposed to normothermic ischemia has been reported [9]. Therefore, minimizing the adverse effects of I/R injury could improve outcomes in steatotic liver surgery, increasing the number of patients who successfully recover from major liver surgery.

Animal models of cold and warm hepatic I/R are valuable tools for understanding the physiopathology of hepatic I/R injury and discovering novel therapeutic targets and drugs. Some of the mechanisms and cell types involved in hepatic I/R injury are described below.

The lack of oxygen in hepatocytes during ischemia causes ATP depletion and alterations in $\mathrm{H}^{+}, \mathrm{Na}^{+}$, and $\mathrm{Ca}^{2+}$ homeostasis that activate hydrolytic enzymes and impair cell volume regulation leading to the swelling of sinusoidal endothelial cells (SECs) and Kupffer cells (KCs) [10]. This fact, together with the imbalance between nitric oxide (NO) and endothelin production, contributes to the narrowing of the 


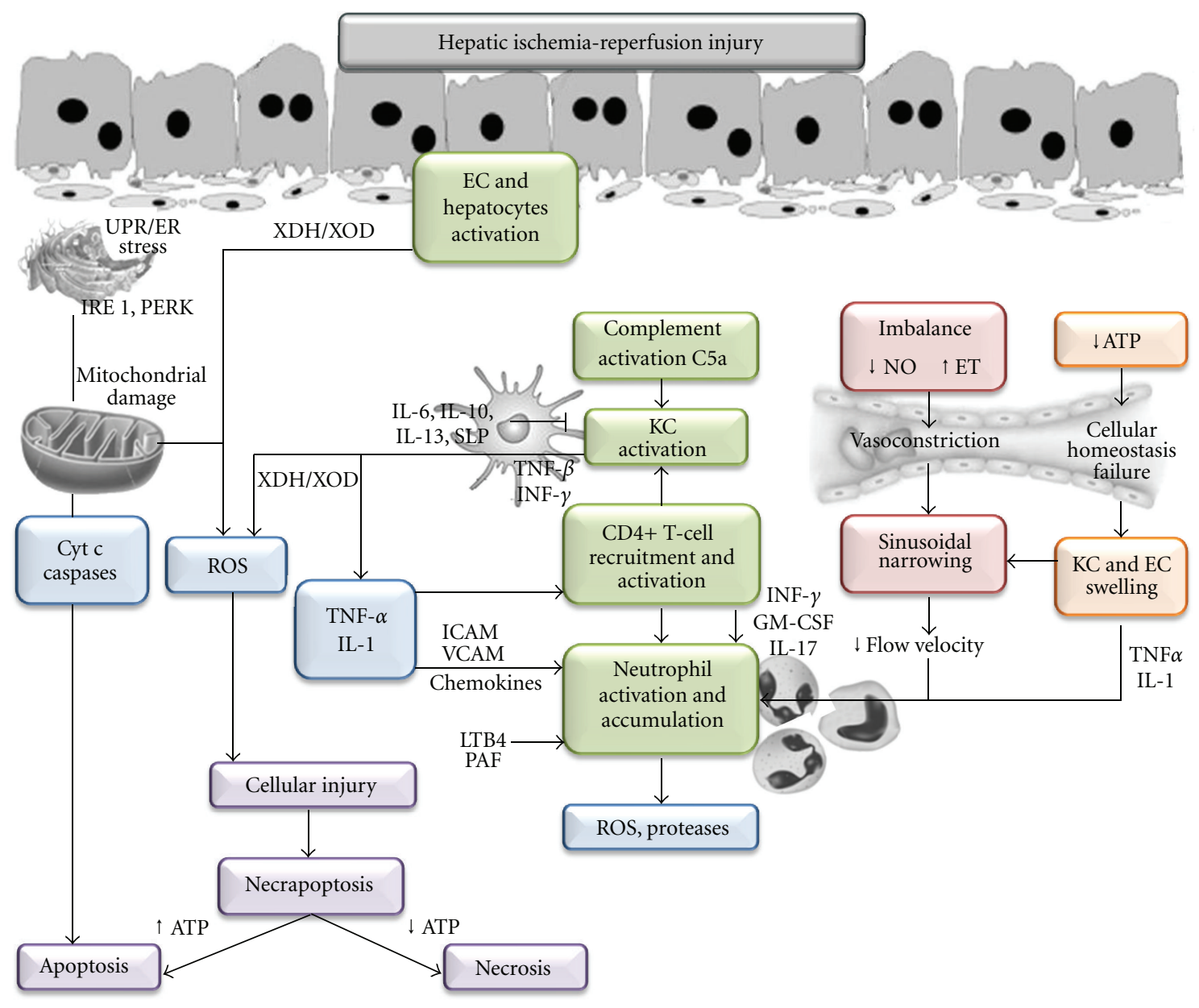

FIGURE 1: Mechanisms involved in hepatic ischemia-reperfusion injury. EC, endothelial cell; ET, endothelin; UPR/ER, unfolded protein response/endoplasmic reticulum; IRE1, inositol-requiring enzyme 1; PERK, PKR-like ER kinase; SLP, secretory leukocyte protease inhibitor; ICAM, intracellular cell adhesion molecule; VCAM, vascular cell adhesion molecule; GM-CSF, granulocyte-macrophage colony-stimulating factor; IL, interleukin; INF, interferon; TNF, tumor necrosis factor; PAF, platelet-activating factor; LTB4, leucotriene B4; KC, Kupffer cell; $\mathrm{X} / \mathrm{XOD}$, xanthine/xanthine oxidase; Cyt c: cytochrome c.

sinusoidal lumen and thus to microcirculatory dysfunction (Figure 1). Capillary narrowing also contributes to hepatic neutrophil accumulation [11]. Concomitantly, the activation of KCs releases reactive oxygen species (ROS) and proinflammatory cytokines, including tumour necrosis factoralpha (TNF- $\alpha$ ) and interleukin-1 (IL-1) [12]. Similar to their production in KCs, ROS can derive from mitochondria and the xanthine dehydrogenase/xanthine oxidase (XDH/XOD) pathway in activated SEC and hepatocytes. Cytokines release through the induction of adhesion molecules (intercellular cell adhesion molecule and vascular cell adhesion molecule), and chemokines promote neutrophil activation and accumulation, thereby contributing to the progression of parenchymal injury by releasing ROS and proteases $[1,3,12]$. In addition, IL- 1 and TNF- $\alpha$ recruit and activate CD4+ $\mathrm{T}$ lymphocytes, which produce granulocyte-macrophage colony-stimulating factor, interferon gamma and TNF- $\beta$ (Figure 1). These cytokines amplify KC activation and TNF- $\alpha$ and IL-1 secretion and promote neutrophil recruitment and adherence into the liver sinusoids [13, 14]. Platelet-activating factor can prime neutrophils for superoxide generation, whereas leukotriene B4 contributes to the amplification of the neutrophil response $[1,3]$.

\section{Experimental Models}

The speed of human studies is slow, the majority of human tissues are not routinely accessible for research purposes, and there is a very limited opportunity for interventional studies. Although scientific research has always relied on the use of cell cultures, information that is obtained through in vitro studies can be extrapolated to biomedical research only when analyzed within a complex organism with metabolic functioning. Therefore, one avenue holding tremendous potential in the search for therapies against I/R damage is the use of intact living systems, in which complex biological processes can be examined. There are many advantages of animal studies: large numbers of animals (especially rodents) 
can be bred and studied, interventional studies can be performed, and established and emerging tools for targeted manipulation of gene expression levels provide insight into the function of mediators in hepatic I/R injury.

Comparison of the results of animal studies and their extrapolation to human beings is feasible, but with limitations. Among the primary obstacles are differences in hypothermia and ischemia tolerance, differences in the anatomy of the livers of various species and subspecies, differences between and within the experimental models used, and differences in the modes of administration, dosage, and metabolic breakdown of the drugs under investigation. Thus, it is very important to choose the animal species and the experimental model and to standardize the protocol according to the clinical question under study.

2.1. Choice of the Animal Model. The species used for experimental investigation of hepatic $\mathrm{I} / \mathrm{R}$ injury range from mice to pigs. Small animals such as mice and rats are exceptionally useful because they are easy to manage, present minimal logistical, financial, or ethical problems, and provide the potential for genetic alterations (e.g., transgenic and knockout animals). However, an important drawback is that the results of studies performed in small animals are of limited applicability to human beings due to their varying size and anatomy of the liver and their faster metabolism [15]. Large animals such as pigs, sheep, and dogs exhibit greater similarity in their anatomy and physiology to human beings. Thus, they are more suited for the study of problems of direct clinical relevance. However, their use is restricted by serious logistical and financial difficulties and often by ethical concerns. Furthermore, the technical possibilities of blood and tissue processing are extremely restricted because of the limited availability of immunological tools for use in large animal species [15].

When selecting an animal species, the age and sex of the animals should be considered. Depending on the duration of ischemia, young (35-50 g) and older rats $(250-400 \mathrm{~g})$ exhibit significant differences in their hepatic microcirculation [16]. A mature rat weighing more than $250 \mathrm{~g}$ (14-16 weeks old) is the most suitable because younger rats can present technical problems, whereas older rats are more prone to respiratory infections and fat accumulation. Sex selection also affects experimental results, as hormone levels in female animals are dependent on the estrous cycle, which certainly affects the ischemia tolerance of the liver. For instance, a study demonstrated that after normothermic liver ischemia, male rats were less sensitive to reperfusion injury than female rats [17].

Considering the relevancy of hepatic steatosis in surgery, experimental models of hepatic I/R injury in the presence of steatosis have been developed. However, the mechanisms involved in hepatic I/R injury, as it will be described in following sections, are different depending on the method used to induce steatosis. The different models of steatosis include (1) induced genetic models such as $\mathrm{db} / \mathrm{db}$ and ob/ob mice and fa/fa rats, (2) animals fed diets with high levels of saturated fat and/or carbohydrates and/or proteins, (3) animals fed diets deficient in methyl groups (choline, methionine, folates), and (4) animals fed modified high-fat diets (lower methionine and choline and higher-fat content) [18].

2.2. Standardization of the Experiment. The induction of $\mathrm{I} / \mathrm{R}$ injury must be performed under standardized experimental conditions. Of primary importance are the conditions under which the animals are kept such as adequate acclimatization time, maintenance under climatized conditions with $12 \mathrm{~h}$ light/12 $\mathrm{h}$ darkness, and standardized diets. The anesthetic method and postoperative analgesic regimen must also be standardized. When choosing the anesthetic and analgesic procedures, possible interactions with liver metabolism must be considered. Attention must be paid to adequate monitoring of blood pressure, heart rate, and body temperature.

\section{Normothermic Ischemia}

3.1. Global Hepatic Ischemia with Portocaval Decompression. The model of global liver ischemia with portal decompression ideally simulates the clinical situation of warm ischemia after the Pringle maneuver for liver resection and LT. The first successful shunt operation in humans was performed by Vidal in 1903 [19]. Blakemore was one of the first workers to report successful portal-systemic anastomosis in rats working principally with endothelium-lined tubes [20]. Burnett et al. modified this technique to form a portocaval shunt [21]. In 1959 Bernstein and Cheiker developed the portosystemic shunt that conducted the portal blood after functional hepatectomy into one of the iliac veins [22]. In small animals, in addition to many other shunt techniques such as the portofemoral shunt and the mesentericocaval shunt via the jugular vein, in 1995, Spiegel et al. developed the splenocaval shunt [23] (Figure 2). In large animals, on the contrary, a portofemorojugular bypass is frequently employed [24].

3.2. Global Liver Ischemia with Spleen Transposition. Bengmark et al. developed this model in 1970 for the surgical treatment of portal hypertension [25]. In 1981 Meredith and Wade presented a rat model that by transposition of the spleen produced a portosystemic shunt in the anhepatic rat [26]. A small incision is made in the left hypochondrium. After transposition of the spleen into a subcutaneous pouch, adequate portosystemic anastomoses arise after 2-3 weeks (Figure 3). Reversal of blood flow in the splenic vein, induced by the transposition, stimulates angiogenesis. In the second step 2 weeks later, the surgeon performs a median laparotomy and temporary occlusion of the hepatoduodenal ligament. This decompression by spleen transposition does not require microsurgical technique and is therefore easy to perform [27]. Two-to-three weeks postoperatively, the spleen will have been encapsulated without any signs of bleeding or inflammation (Figure 3). One disadvantage of this model is the long time lapse ( 3 weeks) until the formation of adequate portosystemic collaterals. Not until this point in time are the collaterals sufficiently large to take over portal vein flow 


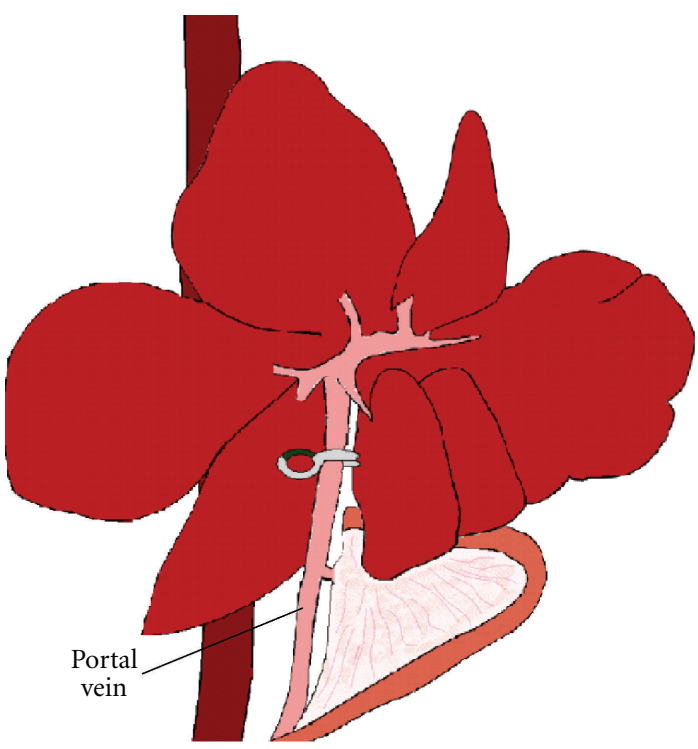

(a)

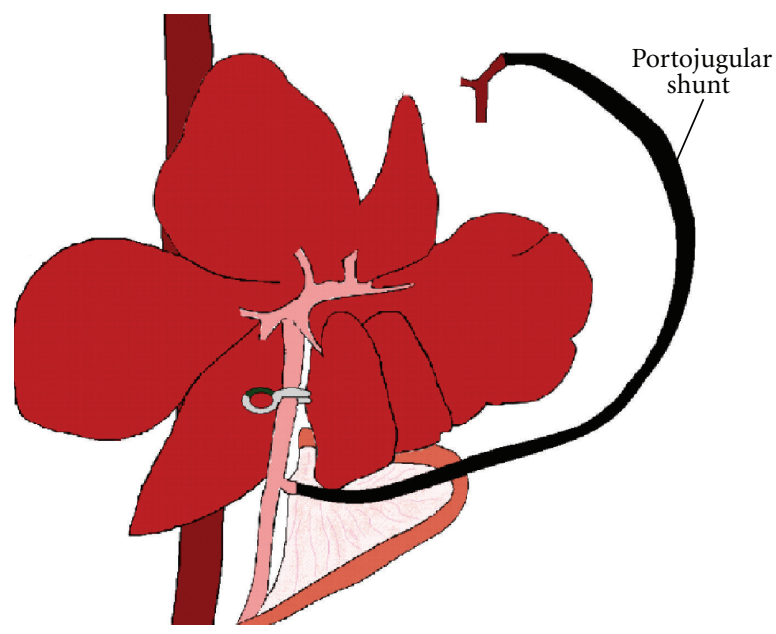

(c)

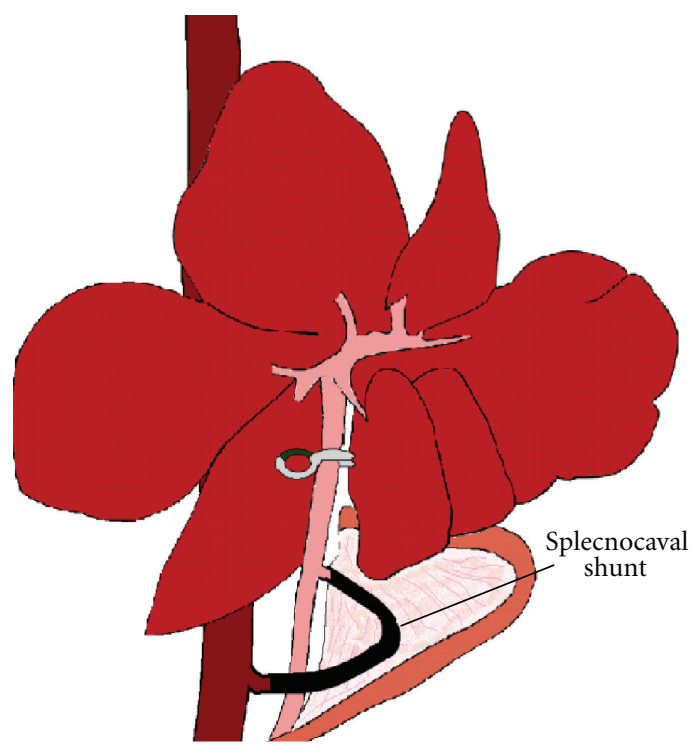

(b)

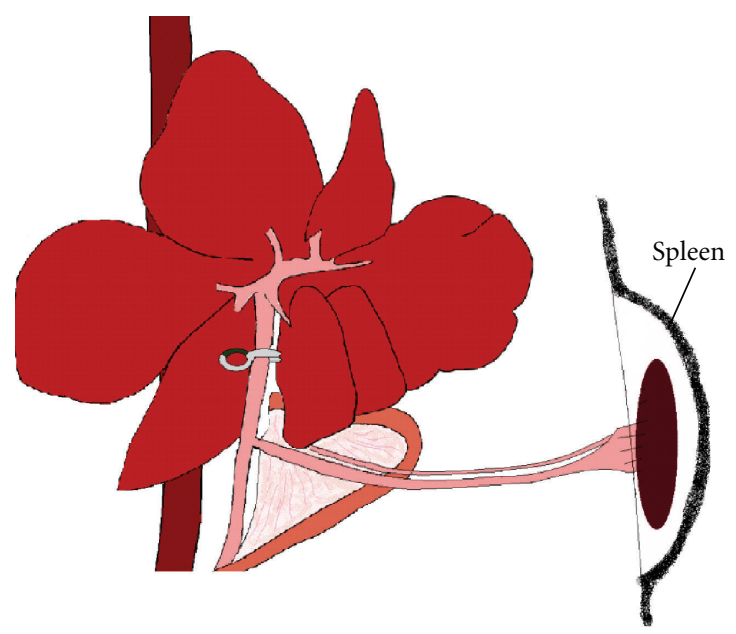

(d)

Figure 2: Models of global normothermic liver ischemia. (a) Pringle maneuver. (b) Splecnocaval shunt. (c) Portojugular shunt. (d) Spleen transposition.

completely. Furthermore, it is uncertain how the changes in hepatic inflow will react upon the collaterals [28].

\subsection{Partial Liver Ischemia. In 1982, Yamauchi et al. and} Hasselgren et al. described a model of hepatic ischemia $[29,30]$. In this technique, ischemia is induced by occlusion of the hepatic artery, the portal vein, and the bile duct of the left and median lobes. An extracorporeal shunt is not necessary because blood flow continues through the right and caudal liver lobes. This model of $70 \%$ partial ischemia has been widely used in experimental studies of hepatic I/R $[31,32]$. Additionally, a experimental model of $30 \%$ partial liver ischemia has been used in which blood supply to the right lobe of the liver is interrupted by occlusion at the level of the hepatic artery and portal vein $[11,33]$.
It is known that, in clinical situations, partial hepatectomy under $\mathrm{I} / \mathrm{R}$ is usually performed to control bleeding during parenchymal dissection. Therefore, the use of a experimental model including both hepatic regeneration and $\mathrm{I} / \mathrm{R}$ injury is advisable to simulate the clinical situation of selective or hemihepatic vascular occlusion for liver resections. In experimental model, after resection of left hepatic lobe, a microvascular clamp is placed across the portal triad supplying the median lobe (30\%). Congestion of the bowel is avoided during the clamping period by preserving the portal flow through the right and caudate lobes. At the end of ischemia time, the right lobe and caudate lobes are resected, and reperfusion of the median lobe is achieved by releasing the clamp. This model of hepatic resection does not require any portal decompression and also 


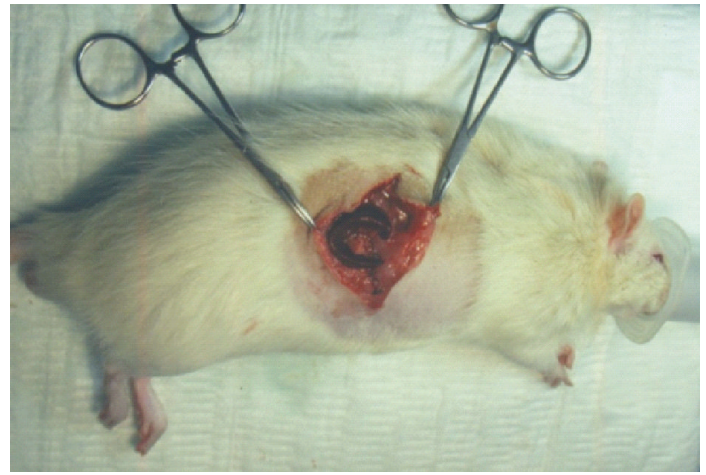

(a)

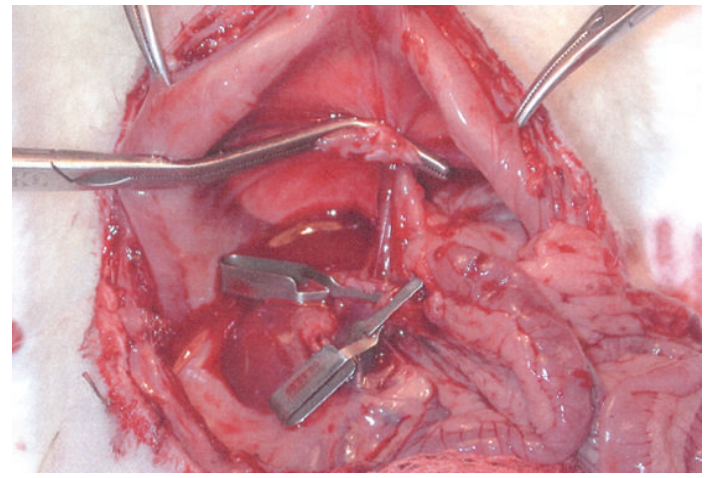

(c)

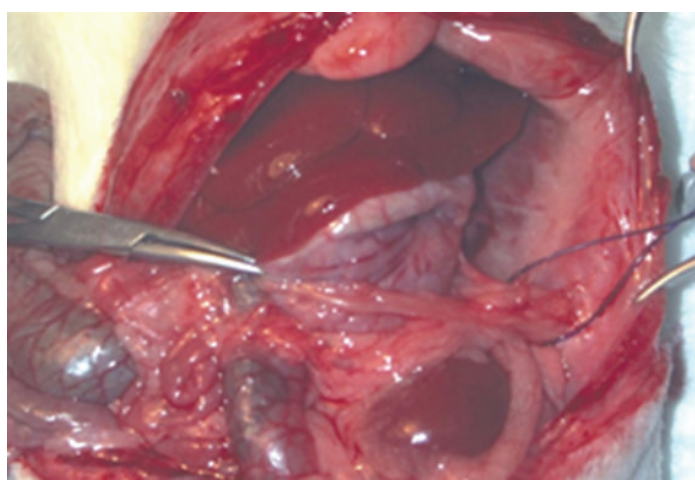

(b)

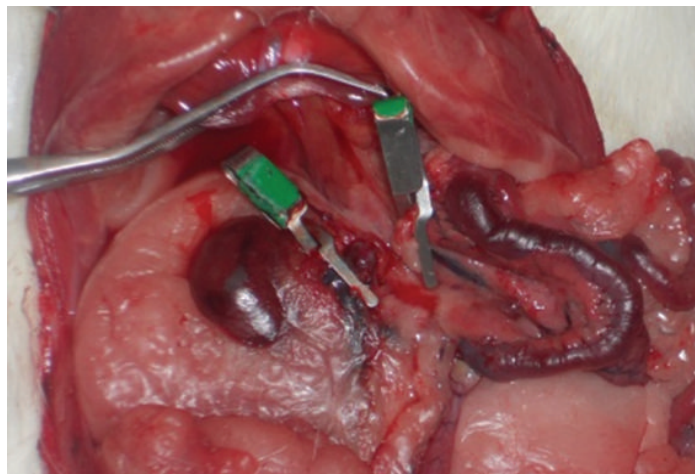

(d)

FIGURE 3: (a) Transposition of the spleen to the subcutaneous tissue in the left hypochondrium. (b) Abdominal cavity after three weeks of the transposition of the spleen. (c) Anhepatic phase in recipient with SPS. No intestinal congestion is observed secondary to clamping of different vessels. (d) Anhepatic phase in recipient without SPS. Intestinal congestion is observed secondary to clamping of the different vessels.

fulfills certain important criteria such as reversibility, good reproducibility, and simple performance [34,35].

\section{Liver Transplantation}

LT in larger laboratory animals such as dogs and pigs is technically easier. However, the rat has become the most important subject for experimental LT because of, among other factors, the availability of genetically defined animals [36].

Orthotopic liver transplantation (OLT) is a common yet complex microsurgical technique. OLT in mice is technically very difficult, even without reconstruction of the hepatic artery. By contrast, OLT in rats is technically accessible, producing more clinically relevant and reliable data [37]. The development of clinically relevant OLT models in rats [37] has advanced clinical knowledge in LT. These experimental models facilitate the study of new preservation methods, tolerance induction, rejection mechanisms, and novel immunosuppressor therapies [38].

OLT in rats was first reported in 1973 using hand-suture techniques [39], and a modified model without hepatic artery reconstruction and temporal shunt of the portojugular venovenous bypass was documented in 1975 [40]. However, these models were not widely used due to the prolonged surgical time and technical demand. With the cuff method being introduced in 1979 by Kamada and Calne [41], OLT in rats without hepatic artery reconstruction became globally accepted [37].

The donor operation, including the harvesting and preparation of the donor liver, is usually performed according to the procedure described by Kamada and Calne [41]. After arterial and portal perfusion, the suprahepatic vena cava is dissected free from the diaphragmatic ring, and the intrathoracic vena cava is transected. The aorta is cut around the celiac axis to form the aortic patch. Finally, the inferior vena cava, the portal vein, and the bile duct are cut, and the graft is placed in a cold preservation solution [42] (Figure 4). OLT is then performed by suture or mechanical microvascular anastomoses. Sutured vascular anastomosis reduces the incidence of thrombosis but takes a long time to perform. Suprahepatic vena cava anastomosis is performed by the continuous suturing technique. Then, portal vein and infrahepatic vena cava anastomosis is performed in the same manner. Hepatic artery reconstruction in rat LT can prevent bile duct ischemia and preserve the structure of the liver [43]. Several techniques of rearterialization by suture have been proposed $[42,43]$, the best being the aortic segment anastomosis technique [42]. After rearterialization, 


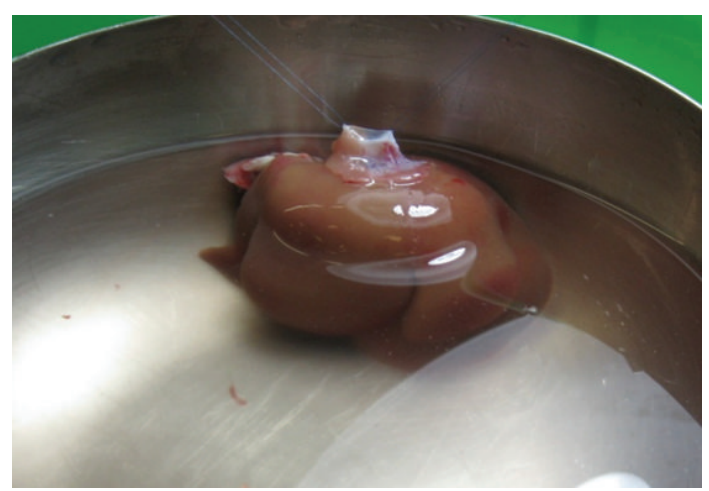

(a)

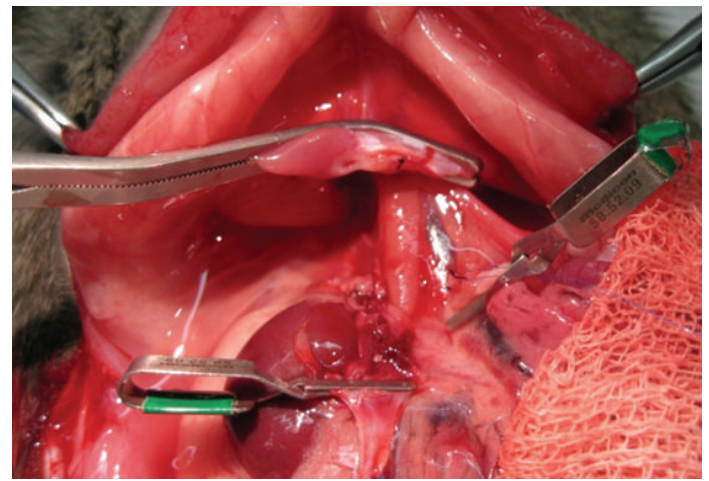

(c)

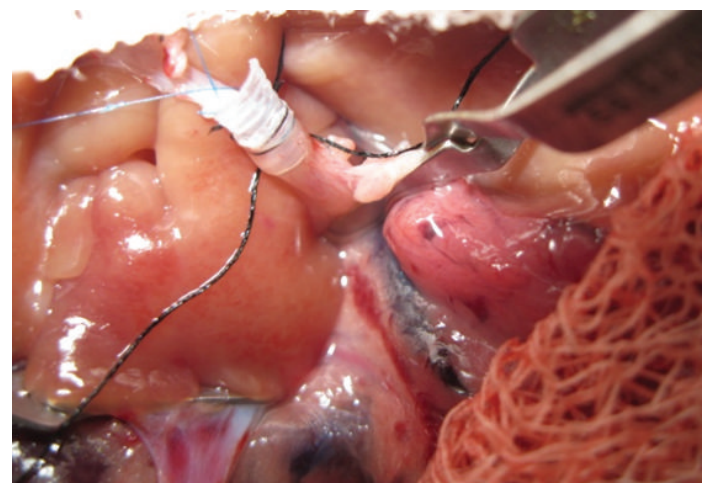

(e)

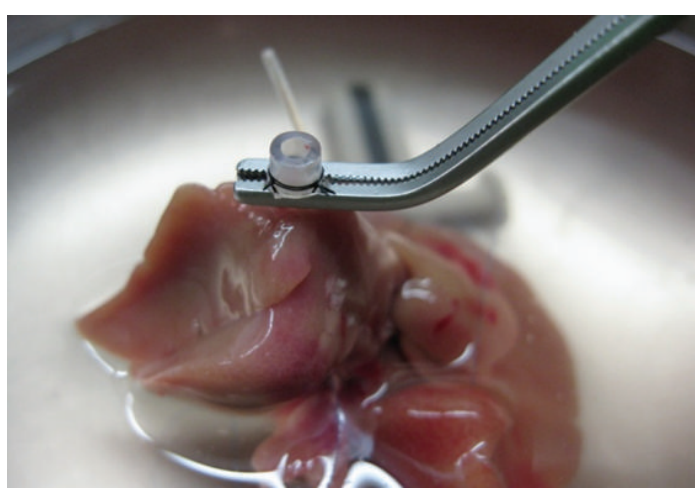

(b)

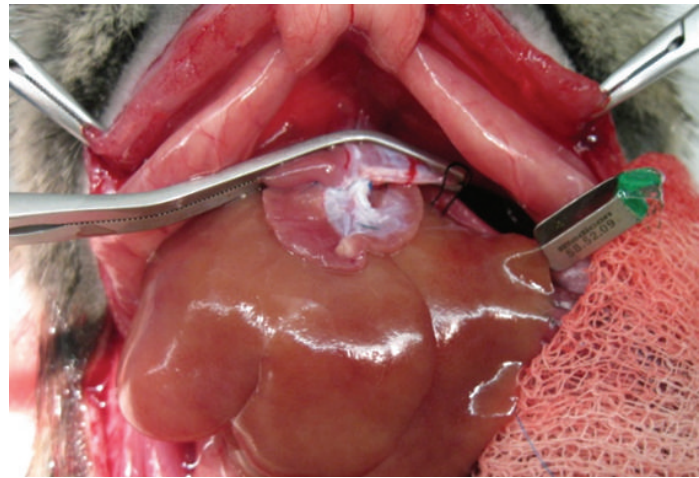

(d)

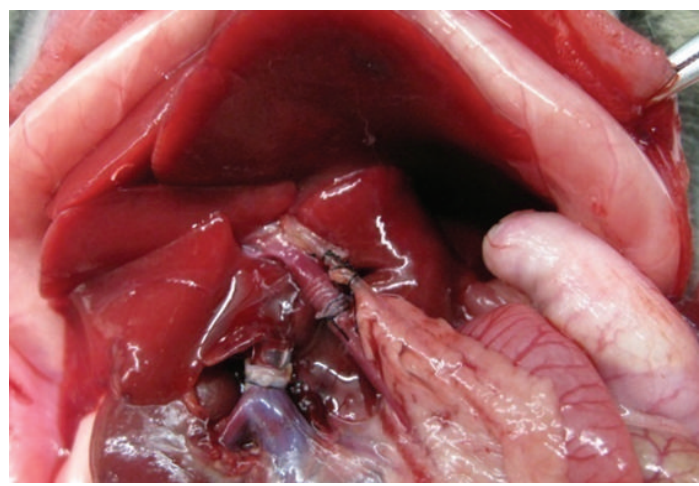

(f)

FIGURE 4: Liver transplantation procedure. (a) Suprahepatic cava vein prepared for the anastomosis. (b) Inferior vein cava cuff attachment. (c) Anhepatic phase in the recipient rat. (d) Anastomosis of suprahepatic cava vein by continuous suture. (e) Portal vein anastomosis through the cuff method. (f) Anastomosis of the bile duct.

the common bile duct is anastomosed. OLT by hand-sewn microanastomosis is a very useful method because this technique comes closest to the techniques used in human transplantation surgery [42]. Alternatively, livers can be satisfactorily allografted in rats by using the rapid cuffligature technique for anastomosis [41, 42]. In the simplified technique, the donor hepatic artery can be ligated because it will not be anastomosed [38]. A mechanical microvascular anastomosis for OLT in the rat using a quick-linker technique that significantly reduces the warm ischaemia time has recently been proposed [44].

In an attempt to expand the size of the donor pool, a number of surgical techniques have been developed over the past 15 years, including split LT and living donor LT [45]. One of the benefits of reduced-size grafts from living donors is a graft of good quality with a short ischemic time, this latter being possible because live donor procurements can be electively timed with the recipient procedure. Conversely, the major concern over the application of living-related LT for adults is graft-size disparity. Small grafts require posterior regeneration to restore the liver/body ratio. It is well known that I/R significantly reduces liver regeneration after hepatectomy [46]. Thus, the identification and subsequent modulation of mechanism that are involved in liver injury and regeneration might favor the recovery and functioning of the transplanted organ. 


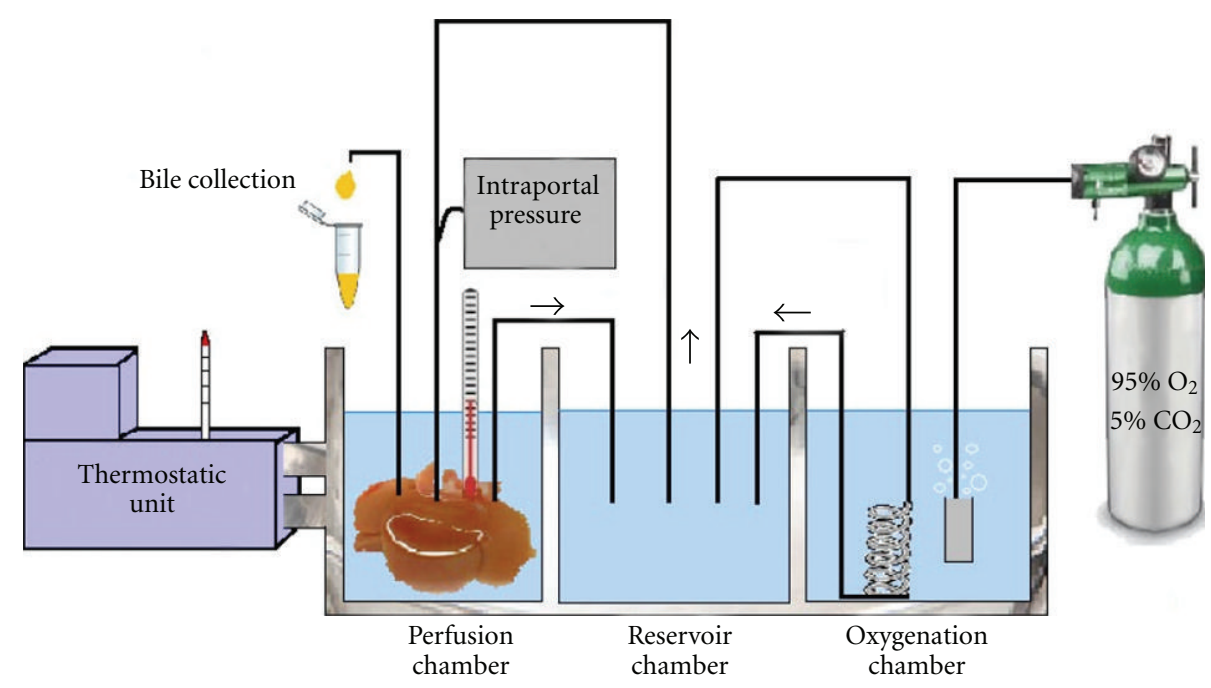

FIGURE 5: Illustrative representation of machine reperfusion.

To mimic some of the pathophysiological events that occur during such clinical situations, several experimental models of reduced-size LT have been developed. For example, OLT with the implantation of liver grafts that approximated $30 \%-70 \%$ of the normal mass of a rat liver has been performed. Graft size is important for normal liver function and host survival [45]. It has been reported that $100 \%$ of recipient rats that were implanted with $40 \%$, $50 \%, 60 \%$, or $70 \%$ of the liver survived regardless of the duration of preservation. This suggests that graft sizes of $40 \%$ or greater are sufficient to meet the metabolic demands of the recipients. The transplantation of a graft of $30 \%$ of the normal liver mass provides an extreme model of hepatic reduction that presumably stimulated a maximal regenerative response [45].

Three possibilities exist with respect to the timing of the graft reduction: in the donor before perfusion, in the container (ex situ), or in the recipient after reperfusion. If the reduction is done in vivo prior to the removal of the donor liver, then two concerns exist (1) excessive bleeding might stimulate systemic responses that could alter the liver and (2) the immediate phase of the regeneration response could be initiated in the donor animal. The second choice, ex situ reduction, can be done without the risk of damaging the graft by manipulation or affecting anastomosis after reperfusion. Finally, resection of the graft after implantation in the recipient adds surgical stress and the risk of bleeding [47].

\section{Optimizing the Graft}

5.1. Static Organ Preservation. The introduction of the University of Wisconsin (UW) solution by Belzer and Southard for static cold storage was a breakthrough and remains the conventional method of preservation. Reduction of metabolic activity (by cooling) is the major principle of organ preservation $[48,49]$. Using this method, however, organs undergo injury at several consecutive stages: warm ischemia prior to preservation, cold preservation injury, ischemic rewarming during surgical implantation, and reperfusion injury [49]. Only a few studies have demonstrated the optimization of graft function and survival with modification of static preservation. It is doubtful that considerable improvements in organ preservation and especially in the rescue of marginal organs will be possible as long as the strategy is based on static principles [48]. The improvements in UW preservation solution are summarized in Table 1.

5.2. Machine Perfusion. Machine liver perfusion has emerged with promising data over the past decade because it has significant potential in graft preservation and even more potential in graft optimization when the use of marginal organs is the objective.

Compared with simple cold storage (SCS), machine perfusion (Figure 5) confers many anticipated advantages such as the following: (1) provision of continuous circulation and better preservation of the microcirculation, (2) continuous nutrient and oxygen delivery to fulfill the organ's metabolic demands, (3) removal of metabolic waste products and toxins, (4) opportunity to assess organ viability, (5) improved clinical outcomes via improved immediate graft function rates, (6) prolonged preservation time without increased preservation damage, (7) administration of cytoprotective and immunomodulating substances, and (8) lower graft dysfunction incidence, shorter hospital stays, and better graft survival rates [50].

5.3. Normothermic Machine Perfusion. Normothermic machine perfusion (NMP) maintains and mimics normal in vivo liver conditions and function during the entire period of preservation, thus avoiding hypothermia and hypoxia and minimizing preservation injury $[48,50]$.

Schön et al. [51] studied NMP to preserve pig livers for transplantation and to rescue them from warm ischemia in a model of donor after cardiac death (DCD). Short $(5 \mathrm{~h})$ or prolonged $(20 \mathrm{~h})$ NMP preservation is superior to SCS 
TABLE 1: Pharmacological treatments to protect liver against ischemia/reperfusion. AMP; activated protein kinase, AMPK; heme oxygenase1, HO-1; interleukin, IL; nitric oxide, NO; peroxisome proliferator-activated receptor- $\alpha$, PPAR- $\alpha$; peroxisome proliferator-activated receptor (PPAR) $\gamma$, PPAR- $\gamma$; reactive oxygen species, ROS; tumour necrosis factor TNF; xanthine dehydrogenase/xanthine oxidase, XDH/XOD.

\begin{tabular}{|c|c|c|c|c|}
\hline \multirow[b]{2}{*}{ Drug } & \multicolumn{3}{|c|}{ Pharmacological therapy } & \multirow[b]{2}{*}{ Effect } \\
\hline & Specie & Experimental model & $\begin{array}{l}\text { Ischemic } \\
\text { time }\end{array}$ & \\
\hline $\begin{array}{l}\text { Chlorpromazine }(\mathrm{Ca} 2+ \\
\text { channel antagonist) }\end{array}$ & Rat & Liver transplantation & $24 \mathrm{~h}$ & $\begin{array}{l}\uparrow \text { ATP, } \downarrow \text { mitochondrial dysfunction and } \\
\text { alterations in lipid metabolism }\end{array}$ \\
\hline \multirow[t]{2}{*}{ Tauroursodeoxy-cholate } & \multirow{2}{*}{ Rat } & Liver transplantation & $8 \mathrm{~h}$ & \multirow{2}{*}{$\downarrow$ Endoplasmic reticulum stress } \\
\hline & & $\begin{array}{l}\text { Warm ischemia }+ \\
\text { hepatectomy }\end{array}$ & $1 \mathrm{~h}$ & \\
\hline $\begin{array}{l}\text { Cbz-Val-Phe methyl ester } \\
\text { (calpain inhibitor) }\end{array}$ & Rat & Liver transplantation & $24,40 \mathrm{~h}$ & $\downarrow$ Calpain activation and SEC apoptotic \\
\hline \multirow{2}{*}{ Tocopherol (antioxidant) } & \multirow{2}{*}{ Rat } & Liver transplantation & $5 \mathrm{~h}$ & \multirow{2}{*}{$\begin{array}{l}\downarrow \text { Lipid peroxidation, } \downarrow \text { SEC damage and } \\
\text { microcirculatory disturbances }\end{array}$} \\
\hline & & Warm ischemia & $45,90 \mathrm{~min}$ & \\
\hline \multirow{2}{*}{ Glutathione (antioxidant) } & \multirow{2}{*}{ Rat } & Warm ischemia & $60,90 \mathrm{~min}$ & \multirow{2}{*}{$\begin{array}{l}\downarrow \text { Microcirculatory disturbances, } \uparrow \\
\text { detoxification of ROS, }\end{array}$} \\
\hline & & Liver transplantation & $24 \mathrm{~h}$ & \\
\hline \multirow[t]{2}{*}{ SOD (antioxidant) } & \multirow[t]{2}{*}{ Rat } & Warm ischemia & $\begin{array}{l}45 \mathrm{~min} \\
\text { and } 1 \mathrm{~h}\end{array}$ & \multirow{2}{*}{$\begin{array}{l}\downarrow \text { Microcirculatory disturbances and } \\
\text { leukocyte accumulation }\end{array}$} \\
\hline & & Liver transplantation & $8 \mathrm{~h}$ & \\
\hline \multirow{2}{*}{$\begin{array}{l}\text { Allopurinol (XOD } \\
\text { inhibitor) }\end{array}$} & \multirow{2}{*}{$\begin{array}{l}\text { Rat, } \\
\text { Mice }\end{array}$} & Liver transplantation & $8,16 \mathrm{~h}$ & \multirow{2}{*}{$\downarrow$ Oxidative stress } \\
\hline & & Warm ischemia & $30,60 \mathrm{~min}$ & \\
\hline Bucillamine (antioxidant) & Rat & Liver transplantation & $24 \mathrm{~h}$ & $\downarrow$ Oxidative stress \\
\hline AMPK activators & Rat & Warm ischemia & $90 \mathrm{~min}$ & $\uparrow \mathrm{NO}$, and ATP \\
\hline Adenosine & Rat & Warm ischemia & $90 \mathrm{~min}$ & $\uparrow \mathrm{NO}$ \\
\hline $\begin{array}{l}\mathrm{N} \text {-acetylcysteine } \\
\text { (glutathione precursor) }\end{array}$ & Rat & Liver transplantation & $24 \mathrm{~h}$ & $\downarrow$ Microcirculatory disturbances \\
\hline \multirow{2}{*}{ L-arginine (NO precursor) } & \multirow[t]{2}{*}{ Rat } & Liver transplantation & $18 \mathrm{~h}$ & \multirow[t]{2}{*}{$\uparrow \mathrm{ATP}, \uparrow \mathrm{NO}, \downarrow$ neutrophil accumulation } \\
\hline & & Warm ischemia & $45 \mathrm{~min}$ & \\
\hline $\begin{array}{l}\text { Spermine NONOate }(\mathrm{NO} \\
\text { donor) }\end{array}$ & Rat & Warm ischemia & $60,90 \mathrm{~min}$ & $\downarrow$ IL- $1 \alpha$ and oxidative stress \\
\hline FK 409 (NO donor) & Rat & Liver transplantation & $80 \mathrm{~min}$ & $\downarrow$ SEC damage, $\downarrow$ IL- $1 \uparrow$ HSP, and IL-10 \\
\hline $\begin{array}{l}\text { EHNA (adenosine } \\
\text { deaminase inhibitor) }\end{array}$ & Rat & Liver transplantation & $24,44 \mathrm{~h}$ & $\begin{array}{l}\uparrow \text { Interstitial adenosine, } \downarrow \text { leukocytes } \\
\text { rolling and microcirculatory disturbances }\end{array}$ \\
\hline $\begin{array}{l}\text { CGS-21680 (adenosine A2 } \\
\text { receptor agonist) }\end{array}$ & Rat & Liver transplantation & $30 \mathrm{~h}$ & $\downarrow$ SEC killing, $\uparrow$ cAMP \\
\hline \multirow[t]{2}{*}{ Anti-TNF antiserum } & \multirow[t]{2}{*}{ Rat } & Liver transplantation & $6,24 \mathrm{~h}$ & \multirow[t]{2}{*}{$\downarrow$ TNF and leukocyte accumulation } \\
\hline & & Warm ischemia & $90 \mathrm{~min}$ & \\
\hline $\begin{array}{l}\text { FR } 167653 \text { (IL- } 1 \beta \text { and } \\
\text { TNF } \alpha \text { suppressor) }\end{array}$ & Rat & Liver transplantation & $48 \mathrm{~h}$ & $\begin{array}{l}\downarrow \text { TNF and IL } 1-\alpha \text { and Kupffer cell } \\
\text { activation }\end{array}$ \\
\hline IL-10 & Rat & Warm ischemia & $60 \mathrm{~min}$ & $\downarrow$ IL- 1 and oxidative stress \\
\hline \multirow{2}{*}{ Anti-ICAM-1 } & \multirow{2}{*}{ Rat } & Liver transplantation & $24 \mathrm{~h}$ & \multirow{2}{*}{$\begin{array}{l}\downarrow \text { Adherence of leukocytes in } \\
\text { postsinusoidal venules }\end{array}$} \\
\hline & & Warm ischemia & $1 \mathrm{~h}$ & \\
\hline PSGL-1 (P-selectin blocker) & Rat & Liver transplantation & $6 \mathrm{~h}$ & $\begin{array}{l}\downarrow \text { Neutrophil infiltration, } \downarrow \text { INF } \gamma, \text { TNF } \alpha \\
\text { and iNOS }\end{array}$ \\
\hline $\begin{array}{l}\text { CS1 peptides (FN- } \alpha 4 \beta 1 \\
\text { interaction blocker) }\end{array}$ & Rat & Liver transplantation & $4 \mathrm{~h}$ & $\begin{array}{l}\downarrow \text { Neutrophil and lymphocyte T } \\
\text { infiltration, } \downarrow \text { TNF } \alpha \text { and iNOS }\end{array}$ \\
\hline $\begin{array}{l}\text { sCR1 (complement } \\
\text { inhibitor) }\end{array}$ & Rat & Liver transplantation & $24 \mathrm{~h}$ & $\begin{array}{l}\downarrow \text { Microcirculatory disturbances, } \downarrow \\
\text { leukocyte adhesion }\end{array}$ \\
\hline $\begin{array}{l}\text { Sodium ozagrel } \\
\text { (thromboxane synthase } \\
\text { inhibitor) }\end{array}$ & Pig & Liver transplantation & $8 \mathrm{~h}$ & $\downarrow$ ET-1 \\
\hline $\begin{array}{l}\text { Glycine (Kupfer cell } \\
\text { modulator) }\end{array}$ & Rat & Liver transplantation & $24 \mathrm{~h}$ & $\downarrow \mathrm{TNF} \alpha$ and neutrophil accumulation \\
\hline
\end{tabular}


Table 1: Continued.

\begin{tabular}{|c|c|c|c|c|}
\hline \multirow[b]{2}{*}{ Drug } & \multicolumn{3}{|c|}{ Pharmacological therapy } & \multirow[b]{2}{*}{ Effect } \\
\hline & Specie & Experimental model & $\begin{array}{l}\text { Ischemic } \\
\text { time }\end{array}$ & \\
\hline $\begin{array}{l}\mathrm{GdCl}_{3} \text { (Kupffer cell } \\
\text { blocker) }\end{array}$ & Rat & Liver transplantation & $24 \mathrm{~h}$ & $\downarrow \mathrm{TNF} \alpha$ and neutrophil accumulation, \\
\hline $\begin{array}{l}\text { Z-DEVD-FMK (caspase } 3 \\
\text { and } 7 \text { inhibitor) }\end{array}$ & Rat & Liver transplantation & $16 \mathrm{~h}$ & $\begin{array}{l}\downarrow \text { Apoptosis, } \uparrow \text { microvascular perfusion } \\
\text { and Bcl-2 }\end{array}$ \\
\hline $\begin{array}{l}\text { Cobalt-protoporphyrin IX } \\
\text { (HO-1 inducer) }\end{array}$ & Rat & Liver transplantation & $6 \mathrm{~h}$ & $\downarrow \mathrm{T}$-cell and macrophages infiltration \\
\hline ANP (vasodilating peptide) & Rat & Liver transplantation & $24 \mathrm{~h}$ & $\downarrow$ Apoptosis, $\uparrow$ PI3K/Akt \\
\hline Hemin (HO-1 inducer) & Rat & Liver transplantation & $6 \mathrm{~h}$ & $\uparrow \mathrm{Bcl}-2$ \\
\hline $\begin{array}{l}\text { Cerulenin (fatty acid } \\
\text { synthase inhibitor) }\end{array}$ & Mice & $\begin{array}{c}\text { Warm ischemia } \\
\text { Liver transplantation }\end{array}$ & $\begin{array}{l}15 \mathrm{~min} \\
80 \mathrm{~min}\end{array}$ & $\downarrow \mathrm{UCP} 2, \uparrow \mathrm{ATP}$ \\
\hline $\begin{array}{l}\text { Doxorubicin (heat shock } \\
\text { proteins inducer) }\end{array}$ & Rat & Liver transplantation & $48 \mathrm{~h}$ & $\downarrow \mathrm{TNF} \alpha, \mathrm{MIP}-2$ and NF $\kappa \mathrm{B}$ \\
\hline Catalase and derivatives & Mice & Warm ischemia & $30 \mathrm{~min}$ & $\downarrow$ Oxidative stress \\
\hline $\begin{array}{l}\text { Rosiglitazone (PPAR- } \alpha \\
\text { agonist) }\end{array}$ & Rat & Warm ischemia & $\begin{array}{l}30,60 \\
90 \mathrm{~min}\end{array}$ & $\uparrow$ Autophagy, $\downarrow$ cytokines \\
\hline $\begin{array}{l}\text { Apocynin (NAPH oxidase } \\
\text { inhibitor) }\end{array}$ & Mice & Warm ischemia & $30 \mathrm{~min}$ & $\downarrow$ Oxidative stress \\
\hline TBC-1269 (PAN selectin) & Mice & Warm ischemia & $90 \mathrm{~min}$ & $\downarrow$ Inflammatory response, $\downarrow$ ERK $1 / 2$ \\
\hline Melatonin (hormone) & Rat & Warm ischemia & $40 \mathrm{~min}$ & $\downarrow$ IKK and JNK pathways \\
\hline Ascorbate (ROS scavenger) & Rat & Warm ischemia & $30 \mathrm{~min}$ & $\downarrow$ Apoptosis \\
\hline $\begin{array}{l}\text { FK506 } \\
\text { (Immunosuppressant) }\end{array}$ & Rat & Warm ischemia & $60,90 \mathrm{~min}$ & $\downarrow \mathrm{TNF}$ \\
\hline $\begin{array}{l}\text { Gabexate mesilate } \\
\text { (Protease inhibitor) }\end{array}$ & Rat & Warm ischemia & $60 \mathrm{~min}$ & $\downarrow$ Leukocyte activation, $\downarrow$ TNF $\alpha$ \\
\hline $\begin{array}{l}\text { OP-2507 (Analogue of } \\
\text { prostacyclin) }\end{array}$ & Rat & Warm ischemia & $60 \mathrm{~min}$ & $\downarrow$ Microcirculatory disturbances \\
\hline $\begin{array}{l}\text { WY-14643 (PPAR- } \alpha \\
\text { agonist) }\end{array}$ & Rat & Warm ischemia & $60 \mathrm{~min}$ & $\begin{array}{l}\downarrow \text { Inflammatory cytokines, } \downarrow \text { oxidative } \\
\text { stress }\end{array}$ \\
\hline$\alpha$-Lipoic acid (Antioxidant) & Rat & Warm ischemia & $90 \mathrm{~min}$ & $\downarrow$ Apoptosis, $\uparrow$ liver regeneration \\
\hline $\begin{array}{l}\text { Sirolimus } \\
\text { (Immunossupressant) }\end{array}$ & Rat & $\begin{array}{c}\text { Warm ischemia }+ \\
\text { hepatectomy }\end{array}$ & $60 \mathrm{~min}$ & $\downarrow$ Linfocytes \\
\hline $\begin{array}{l}\text { IL-1ra (IL-1 receptor } \\
\text { antagonist) }\end{array}$ & Rat & $\begin{array}{l}\text { Warm ischemia }+ \\
\text { hepatectomy }\end{array}$ & $90 \mathrm{~min}$ & $\downarrow$ TNF and oxidative stress \\
\hline FK 3311 (Cox-2 Inhibitor) & Dog & Warm ischemia & $60 \mathrm{~min}$ & $\downarrow$ Cox- $2, \downarrow$ neutrophil infiltration \\
\hline
\end{tabular}

for normal and ischemically damaged livers, respectively [50]. The NMP circuit dually perfuses $1.5 \mathrm{~L}$ of autologous heparinized blood at physiological pressures, which allows hepatic blood flow autoregulation. Prostacyclin, taurocholic acid, and essential amino acids are infused continuously. Apart from logistics, one potential drawback of NMP is the mandatory use of oxygen carriers if blood is not available [50]. Perhaps the only weakness is that SCS prior to NMP revokes its beneficial effect. Therefore, immediately after cardiac asystole, normothermic perfusion in the donor should be installed, as described by Fondevila et al. [52], for the preservation of livers from uncontrolled DCD.

The use of non-heart-beating donors (NHBDs) as a source of liver grafts for transplantation has long been debated. The concept of normothermic recirculation in the context of NHBDs was first developed by GarcíaValdecasas and Fondevila [53]. With $4 \mathrm{~h}$ of NMP, hepatic damage incurred during $90 \mathrm{~min}$ of cardiac arrest can be reverted, achieving $100 \%$ graft survival after 5 days of postransplant followup. These results offer the hope that NMP will be able to increase the clinical applicability of NHBD LT over that offered by traditional cold storage [53].

5.4. Hypothermic Machine Perfusion. For decades, cooling down organs to cold temperatures allowed successful organ transplantation within a limited period. The first and most prominent difference between SCS and (oxygenated) hypothermic machine perfusion (HMP) is the restoration of the tissue's energy charge and glycogen content while preventing ATP depletion [50]. In 1990, Pienaar et al. [54] 
reported that seven of eight dogs survived after LT with HMP preservation for $72 \mathrm{~h}$ and a similar outcome after $48 \mathrm{~h}$ of SCS.

There is a substantial body of research, predominantly in rodents, demonstrating improved preservation by providing oxygen to livers [55]. Nevertheless, clear guidelines towards target values/ranges for oxygen levels regarding the optimal duration of oxygenation during HMP are lacking. HMP can also be applied at the end of the cold storage period, which is attractive for logistical reasons. The disadvantage here is the time-dependent increase in vascular resistance, bearing the risk of damage to the sinusoidal endothelium [48].

5.5. Subnormothermic Machine Perfusion. Subnormothermic machine perfusion (SNMP) preservation lies between HMP and NMP, but it remained relatively unexplored until recently despite holding promising applications [56]. In an isolated rat liver perfusion model, SNMP enhanced the functional integrity of steatotic livers compared with SCS findings. Organ-protecting properties mediated by decreasing the temperature to a $20-28^{\circ} \mathrm{C}$ have been observed previously. SNMP avoids some of the downsides of hypothermia while maintaining mitochondrial function, and it may circumvent the logistical restraints of NMP [50].

\section{Factors to Be Considered before the Selection of an Experimental Model of Hepatic I/R}

Many investigators have used rodent models of warm (in situ) liver $\mathrm{I} / \mathrm{R}$ to mimic some of the pathophysiological events that occur during LT. Although a great deal of useful information has been generated from these studies, an overriding question remains: Are the mechanisms responsible for transplant-mediated liver injury and dysfunction the same as those that have been reported for warm liver $\mathrm{I} / \mathrm{R}$ injury? The answer is yes and no; that is, some of the mechanisms are similar, but many are dissimilar. It is important to make a distinction between the different types of ischemia, because there already is some controversy regarding the pathophysiological mechanisms depending on the type of ischemia (cold or normothermic), and it should be considered that the type of ischemia, the extent and time of ischemia, the type of liver submitted to $I / R$, and the presence of liver regeneration, all lead to differences in the pathophysiological mechanisms of hepatic I/R. These are discussed below to provide the reader with a guide to select the appropriate experimental model of hepatic I/R depending on the aims being pursued.

6.1. Relevance of the Duration of Hepatic Ischemia. The severity of hepatocyte damage depends on duration of ischemia. Depending on the objectives of the research, it is important to consider a specific ischemia duration. In other words, if you want to study the mechanisms involved in hepatic $\mathrm{I} / \mathrm{R}$ injury or the protective mechanisms of a drug, it is more appropriate to use a duration of ischemia associated with high survival. If the purpose is to study the relevance of a drug in hepatic I/R injury, then it is advisable to assess survival, and, therefore, it is more adequate to use experimental models in which the ischemic period is associated with low survival. These observations are based on the following data reported in the literature. It appears that short periods $(60 \mathrm{~min})$ of warm ischemia result in reversible cell injury, in which liver oxygen consumption returns to control levels when oxygen is resupplied after ischemia. Reperfusion after more prolonged periods of warm ischemia (120-180 min) results in irreversible cell damage. These observations agree with a previous report on rat liver subjected to I/R, indicating a cellular endpoint for hepatocytes after $90 \mathrm{~min}$ of ischemia [57]. In human LT, a long ischemic period is a predicting factor for posttransplantation graft dysfunction, and some transplantation groups hesitate to transplant liver grafts preserved for more than $10 \mathrm{~h}$ [58]. Some studies in experimental models of LT indicate that cold ischemia for $24 \mathrm{~h}$ induces low survival at $24 \mathrm{~h}$ after LT. However, LT, following shorter ischemic periods, may also result in primary organ dysfunction. For animals subjected to $8 \mathrm{~h}$ of cold ischemia, an ischemic period associated with high survival, histological examination of the livers at $24 \mathrm{~h}$ after LT revealed multifocal and extensive areas of hepatocyte coagulative necrosis with neutrophil infiltration and hemorrhage $[10,59]$.

The mechanisms of hepatic I/R injury are also different depending on the duration of hepatic ischemia. For instance, to clarify the importance of $\mathrm{XDH} / \mathrm{XOD}$ versus mitochondria, it should be considered that there are differences in the experimental models evaluated, including the duration of ischemia. Along these lines, $\mathrm{XDH} / \mathrm{XOD}$ plays a crucial role in hepatic I/R injury only in conditions under which significant conversion of XDH to XOD occurs (80-90\% of XOD) such as $16 \mathrm{~h}$ of cold ischemia. However, this ROS generation system does not appear to be crucial for shorter ischemic periods such as $6 \mathrm{~h}$ of cold ischemia [59]. Thus, even after prolonged periods of ischemia during which a significant conversion of XDH to XOD occurs, these enzymes may only play a minor role compared to mitochondria [60]. Similarly, in assessing the relative contribution of intracellular versus vascular oxidant stress to hepatic I/R injury, it should also be noted that oxidative stress in hepatocytes and the stimulatory state of KCs after I/R depend on the duration of ischemia and may also differ between ischemia at $4^{\circ} \mathrm{C}$ and that at $37^{\circ} \mathrm{C}$, which probably leads to different developmental mechanisms of liver damage [13].

6.2. Relevance of the Extent of Hepatic Ischemia. Another factor to consider before selecting the experimental model of hepatic I/R is the percentage of hepatic ischemia applied. It is known that the extent of hepatic injury as well as the hepatic $\mathrm{I} / \mathrm{R}$ mechanisms, including the recovery of blood flow and energy charge during hepatic reperfusion, is dependent on the extent of ischemia-whether total or partial $(70 \%)$ hepatic ischemia is applied [34, 35]. This fact could be explained by the stealing phenomenon. In contrast to $100 \%$ hepatic ischemia, during ischemia in the left and median lobes, the flow is shunted via the right lobes and following the release of the occlusion of the left and median lobes, a significant amount of shunting via the right lobes will 
continue during reperfusion until vascular resistance in the postischemic lobes decreases. This occurs because blood flows through the path of least resistance. The reasons for this may be cellular swelling endothelial, stasis, or other changes. Thus, the recovery of blood flow and hepatic perfusion of the preischemic lobe is later in the case of $70 \%$ hepatic ischemia than in 100\% hepatic ischemia [61]. In line with these observations, the benefits of some drugs such as ATP$\mathrm{MgCl} 2$ were dependent on the extent of hepatic ischemia used $[30,62]$.

6.3. Relevance of the Type of Liver Submitted to I/R. A variety of clinical factors including starvation, graft age, and steatosis have been studied in different experimental models of hepatic I/R because of the relevance of these factors in clinical practice. These factors enhance liver susceptibility to $\mathrm{I} / \mathrm{R}$ injury, further increasing the patient risks related to reperfusion injury [13].

6.3.1. Starvation. In clinical LT, starvation of the donor, due to prolonged intensive care unit hospitalization or the lack of adequate nutritional support, increases the incidence of hepatocellular injury and primary nonfunction [63]. Fasting exacerbates $\mathrm{I} / \mathrm{R}$ injury because the low content of glycogen stores results in more rapid ATP depletion during ischemia [64]. In addition, fasting causes alterations in tissue antioxidant defenses, accelerates the conversion of XDH to XOD during hypoxia and induces mitochondrial alterations [63].

Considering these observations, an artificial nutritional support may represent a new approach for the prevention of reperfusion injury in fasted livers [65]. On the contrary, fasting has been reported to improve organ viability and survival [66], as it reduces phagocytosis and the generation of TNF- $\alpha$ [66]. To understand these apparent contradictory results, it is important to consider the different experimental conditions in these investigations. A beneficial effect of high glycogen content can mainly be expected under conditions of long preservation times and long periods of warm ischemia. Under these conditions, high metabolic reserves of the liver may attenuate ischemic cell injury and preserve defense functions against cytotoxic mediators of KCs. Conversely, short ischemic periods require lower metabolic reserves, and the extent of $\mathrm{KC}$ activation can be the dominant factor in early graft injury [10].

6.3.2. Age. A number of distinct age-related alterations have been identified in the hepatic inflammatory response to hepatic I/R [10, 67]. Under warm hepatic ischemia, mature adult mice had greatly increased neutrophil function, increased intracellular oxidant levels, and decreased mitochondrial function compared with the findings in young adult mice. These alterations contributed to the increased liver injury after $\mathrm{I} / \mathrm{R}$ observed in mature adult mice compared with that in young adult mice. The results obtained in an experimental model of isolated perfused liver indicate that, during reperfusion, livers obtained from old rats generate a lower amount of oxyradicals than livers from young rats. This fact could be explained by the lower KC activity, the reduction of liver blood flow, and the impaired functions and structural alterations observed in the livers of old rats [68]. In fact, in hepatocytes from mature adult mice, delayed activation of nuclear factor kappa B $(\mathrm{NF} \kappa \mathrm{B})$ in response to TNF- $\alpha$ and virtually no production of macrophage inflammatory protein 2 have been detected, which may be due to an agerelated defect in hepatocytes [10,67].

6.3.3. Steatosis. The first step to minimize the adverse effects of $\mathrm{I} / \mathrm{R}$ in steatotic livers is a full understanding of the mechanisms involved in I/R injury in these marginal organs [10]. This can be achieved only with the selection of an appropriate method to induce steatosis in livers undergoing $\mathrm{I} / \mathrm{R}$. It is well known that the mechanisms involved in hepatic I/R injury are different depending on the type of liver (nonsteatotic versus steatotic livers). In addition to the impairment of microcirculation, mitochondrial ROS generation dramatically increases during reperfusion in steatotic livers [69-71]. Results obtained under warm hepatic ischemia indicate that apoptosis is the predominant form of hepatocyte death in the ischemic nonsteatotic liver, whereas the steatotic livers develop massive necrosis after an ischemic insult [72]. Steatotic livers differed from nonsteatotic livers in their response to the unfolded protein response and endoplasmic reticulum stress since inositol-requiring enzyme 1 and PKR-like ER kinase were weaker in the presence of steatosis [73]. Decreased ATP production and dysfunction of regulators of apoptosis, such that $\mathrm{Bcl}-2, \mathrm{Bcl}-\mathrm{xL}$ and $\mathrm{Bax}$ have been proposed to explain the failure of apoptosis in steatotic livers. Differences were also observed when we analyzed the role of the renin-angiotensin system, as the nonsteatotic grafts exhibited higher angiotensin (Ang)-II levels than steatotic grafts whereas steatotic grafts exhibited higher Ang-(1-7) levels [74]. Moreover, reduced retinolbinding protein 4 and increased peroxisome proliferatoractivated receptor gamma (PPAR)- $\gamma$ levels were observed in steatotic livers compared to nonsteatotic livers [75]. The vulnerability of steatotic livers subjected to warm ischemia is also associated with increased adiponectin, oxidative stress, and IL-1 levels and a reduced ability to generate IL-10 and PPAR- $\alpha[31,76]$.

It should be considered that there are differences in the mechanisms involved in hepatic I/R injury depending on the method used to induce steatosis. In contrast with other experimental models of steatosis, both dietary high fat and alcohol exposure induced the production of superoxide dismutase (SOD)/catalase-insensitive ROS, which may be involved in the mechanism of steatotic liver failure after OLT [77]. Neutrophils have been involved in the increased vulnerability of steatotic livers to $\mathrm{I} / \mathrm{R}$ injury, especially in alcoholic steatotic livers. However, neutrophils do not account for the differentially greater injury in nonalcoholic steatotic livers during the early or late hours of reperfusion. Similarly, the role of TNF in the vulnerability of steatotic livers to I/R injury may be dependent on the type of steatosis $[4,78]$.

6.4. Relevance of Regeneration in Experimental Models of Hepatic $I / R$. It is known that different experimental models 
trigger different responses when a common mechanism or the same drug is investigated. This situation is witnessed when analyzing liver injury in models of I/R with or without hepatectomy. This situation is illustrated by Ramalho et al. [34] regarding the loss of protection of Ang-II receptor antagonists against liver damage in conditions of partial hepatectomy under I/R compared with the study of I/R without hepatectomy, in which Ang-II receptor antagonists reduced hepatic damage. These different results could not be explained by differences in the dose or frequency of drug administration but rather by differences in surgical conditions (percentage of hepatic ischemia and the presence or absence of hepatectomy). In the model of I/R without hepatectomy [32], the blood supply to the left and median liver lobes (70\% hepatic mass) was interrupted, and the other hepatic lobes remained intact. However, in partial hepatectomy under $\mathrm{I} / \mathrm{R}$, only blood supply to the remnant liver (30\% hepatic mass) was interrupted and the other hepatic lobes were excised [34]. It is well known that the mechanisms of hepatic damage are different depending on the percentage of hepatic mass that is deprived of blood $[10,61,62]$. In addition, the inherent mechanisms of hepatic damage derived from the extensive removal of hepatic mass should be considered [34].

In line with the data above mentioned, ischemic preconditioning (IP) (a surgical strategy that exert benefits in hepatic I/R) reduced XDH/XOD in nonreduced liver grafts during cold ischemia [72] whereas IP did not induce changes in this ROS generating system in reduced-size liver grafts [46]. In contrast to the conditions of $I / R$ without hepatectomy [79], hepatic regeneration was not correlated to the ATP levels of the remaining liver in small-for-size liver grafts [46]. The reduction in TNF release following hepatic $\mathrm{I} / \mathrm{R}$ induced by IP has been previously reported in cold ischemia conditions without hepatectomy [72]. However, IP did not modify the levels of TNF in reduced-size liver grafts after transplantation [46].

\section{Strategies Applied in Experimental Models of Hepatic I/R}

7.1. Pharmacological Treatment. Numerous experimental studies have focused on the developing pharmacological strategies aimed at inhibiting the harmful effects of $I / R$ $[13,59,73,76,79-88]$. Some of these studies are summarized in Table 1. However, none of these treatments has managed to prevent hepatic I/R injury. The possible side effects of some drugs may frequently limit their use in human LT [13]. For example, idiosyncratic liver injury in humans is documented for chlorpromazine, pernicious systemic effects have been described for NO donors, allopurinol therapy can cause hematological changes and gadolinium can induce coagulation disorders [13]. Some case reports of acute hepatotoxicity attributed to rosiglitazone have been published [89]. High dose of resveratrol aggravated liver injury [90]. The development of therapeutic strategies that utilize the protective effect of heme oxygenase- 1 induction is hampered by the fact that most pharmacological inducers of this enzyme perturb organ function by themselves [91].

Pharmacological treatment-derived difficulties must also be considered. In this regard, SOD and glutathione exhibit inadequate delivery to intracellular sites of ROS action [92]. The administration of anti-TNF antibodies does not effectively protect against hepatic I/R injury, and this finding has been related to the failure of complete TNF- $\alpha$ neutralization locally [93]. Although this also occurs in nonsteatotic livers, modulating I/R injury in steatotic livers poses a greater problem. Differences in the action mechanisms between steatotic and nonsteatotic livers mean that therapies that are effective in nonsteatotic livers may prove useless in the presence of steatosis, and the effective drug dose may differ between the two liver types. Findings such as these must be considered when applying pharmacological strategies in the same manner to steatotic and nonsteatotic livers because the effects may be very different. For example, caspase inhibition, a highly protective strategy in nonsteatotic livers, had no effect on hepatocyte injury in steatotic livers [70]. Moreover, whereas in an LT experimental model, an NO donor reduced oxidative stress in nonsteatotic livers, the same dose increased the vulnerability of steatotic grafts to I/R injury [94]. Furthermore, there may be drugs that would only be effective in steatotic livers. This was the case of compounds such as cerulenin, which reduce UCP-2 expression in steatotic livers [95, 96] and carnitine [97].

Further investigations are required to optimize some treatments because long-term therapy (more of 10 days) appears to be necessary to exert the desired effects [98]. However, there are obvious difficulties concerning the feasibility of long-term drug administration in some I/R processes, in particular, LT from cadaveric donors, because this is an emergency procedure in which there is very little time to pretreat the donor with drugs.

\subsection{Preservation Solutions}

7.2.1. Additives in Preservation Solutions. The inclusion of some components in the UW solution has been both advocated and criticized. For instance, adenosine has been added to the UW solution as a substrate for the generation of adenine nucleotides. However, simplified variants of the UW solution in which adenosine was omitted were demonstrated to have similar or even higher protective potential during cold liver storage. Another limitation of the UW solution is that some of its constituent compounds (allopurinol, lactobionate) do not offer very good protection because they are not present at a suitable concentration and encounter problems in reaching their site of action $[13,99]$.

A number of ingredients, which have been summarized in Table 2, have been introduced into UW solution in experimental models of hepatic cold ischemia [13, 100106]. However, none of these modifications to the UW solution composition have found their way into routine clinical practice. For instance, studies aimed at enriching the UW solution with caspase inhibitors revealed that this prevents SEC apoptosis, but such inhibitors have little effect 
TABLE 2: Additives to UW solution to protect liver against ischemia/reperfusion. Nitric oxide, NO; platelet-activating factor, PAF; sinusoidal endothelial cells, SEC.

\begin{tabular}{|c|c|c|c|}
\hline \multicolumn{4}{|c|}{$\begin{array}{l}\text { Additives to UW solution } \\
\text { Liver transplantation }\end{array}$} \\
\hline Drug & Specie & Ischemic time & Effect \\
\hline $\begin{array}{l}\text { Ruthenium red (mitochondrial } \\
\mathrm{Ca}^{2+} \text { uniporter inhibitor) }\end{array}$ & Rat & $24 \mathrm{~h}$ & $\downarrow$ Mitocondrial dysfunction \\
\hline OP-4183 (PGI2 analogue) & Rat & $24 \mathrm{~h}$ & $\downarrow$ Oxidative stress \\
\hline SAM (ATP precursor) & Rat & $24 \mathrm{~h}$ & $\downarrow$ Oxidative stress \\
\hline $\begin{array}{l}\text { Trifluoperazine (calmodulin } \\
\text { inhibitor) }\end{array}$ & Dog & $24 \mathrm{~h}$ & $\begin{array}{l}\downarrow \text { Microcirculatory } \\
\text { dysturbances }\end{array}$ \\
\hline Sodium nitroprusside (NO donor) & Rat & $24,48 \mathrm{~h}$ & $\begin{array}{l}\downarrow \text { Microcirculatory } \\
\text { dysturbances }\end{array}$ \\
\hline E5880 (PAF antagonist) & Pig & $8 \mathrm{~h}$ & $\begin{array}{l}\downarrow \text { Microcirculatory } \\
\text { dysturbances }\end{array}$ \\
\hline FR167653 (p38 inhibitor) & Rat & $30 \mathrm{~h}$ & $\begin{array}{l}\downarrow \text { Microcirculatory } \\
\text { dysturbances }\end{array}$ \\
\hline EGF, IGF-1, NGF- $\alpha$ & Pig & $18 \mathrm{~h}$ & $\uparrow$ ATP \\
\hline LY294002 (PI3K inhibitor) & Rat & $3,7,9,24 \mathrm{~h}$ & $\downarrow$ Apoptosis \\
\hline IDN-1965 (caspase inhibitors) & Rat & $24,30 \mathrm{~h}$ & $\downarrow$ Apoptosis \\
\hline $\begin{array}{l}\text { 8br-cAMP and 8br-cGMP } \\
\text { (nucleotide analogs) }\end{array}$ & Rat & $24 \mathrm{~h}$ & $\begin{array}{l}\downarrow \mathrm{NF} \alpha \text { and neutrophil } \\
\text { accumulation, }\end{array}$ \\
\hline GSNO (NO donor) & Rat & $48 \mathrm{~h}$ & $\downarrow$ SEC damage \\
\hline Pifithrin-alpha (p53 inhibitor) & Rat & $24,48 \mathrm{~h}$ & $\downarrow$ Apoptosis \\
\hline OP-4183 (PGI2 analogue) & Rat & $24 \mathrm{~h}$ & $\downarrow$ Oxidative stress \\
\hline Tauroursodeoxy-cholate & Rat & $2 \mathrm{~h}$ & $\begin{array}{l}\downarrow \text { Endoplasmic reticulum } \\
\text { stress }\end{array}$ \\
\hline
\end{tabular}

on necrosis [14]. Along these lines, the addition of precursors for ATP resynthesis such as S-adenosyl methyltransferase resulted in poor initial ATP recovery during liver reperfusion [107].

7.2.2. Use of Perfluorochemicals in Preservation Solutions. Perfluorochemicals (PFC) are hydrocarbons, in which all or most of the hydrogen atoms have been replaced with fluorine [108]. The most interesting property of PFC is a very high capacity for dissolving respiratory and other nonpolar gases. A negligible $\mathrm{O}_{2}$-binding constant of PFC allows them to release $\mathrm{O}_{2}$ more effectively than hemoglobin into the surrounding tissue (acts as an oxygen-supplying agent) [109]. PFC differs from hemoglobin preparations in that it is a totally synthetic compound formed on a liquid hydrocarbon base. In contrast to hemoglobin, oxygen is not chemically bound to the PFC carrier. Unlike hemoglobin, acidosis, alkalosis, and temperature seem to have no or little effect on the oxygen delivery of PFC, allowing this compound to be used effectively during cold storage of organs [110].

Since the 1980s, PFC has been used intravenously as an "artificial blood" [111]. Several small animal studies have reported the beneficial effects of liver perfusion with PFC emulsions. PFC was first used for liver graft preservation in 1980 by Kamada et al. [112] which perfused the livers of rat with a PFC Fluosol (FC-43)-based solution for up to $25 \mathrm{hr}$, demonstrating good survival rates after transplantation and beneficial effect of PFCs $[111,112]$. By using a similar rat model, Tamaki et al. [113] showed that liver perfusion using a combination of hemaccel-isotonic citrate solution with FC-43 could prolong liver preservation for up to $48 \mathrm{hr}$. In another liver rodent model, perfusion with a PFC emulsion was also found to protect against nonparenchymal cell injury [114]. Nonetheless, these techniques were not translated successfully to the porcine liver with a report of increased intravascular resistance during perfusion [115]. In this report the authors concluded that possible causes related to the high instability of the PFC-based solution, causing complement activation leading to an increased leucocyte adhesion and further macromolecules or that the perfusion technique itself caused injury (a strong vasoconstriction caused by the inflow of cold PDF-UW emulsion) $[115,116]$. In recenting study, used oxycyte, a PFC added to UW solution can be beneficial after cardiac death liver graft preservation in a rat model [111]. In such study, after cardiac arrest, livers were flushed and preserved during $8 \mathrm{~h}$ in preoxygenated UW solution containing Oxycyte. The authors show that the primary mechanism of action is due to PFC's ability to carry high amounts of $\mathrm{O}_{2}$ along with rapid dissociation in the tissue. This can help to minimize organ injury after prolonged hypoxia. A possible secondary mechanism of this $\mathrm{O}_{2}$ action is suppression of hypoxia-induced apoptosis mediated through a mitochondrial pathway. PFC also appears to activate downregulation or reversal of gene activation responsible 
TABLE 3: Gene therapy to protect liver againts ischemia/reperfusion. Heme oxygenase-1, HO-1; interleukin-13, IL-13; small interference RNA, siRNA; superoxide dismutase, SOD; tumour necrosis factor TNF.

\begin{tabular}{|c|c|c|c|c|}
\hline \multicolumn{5}{|c|}{ Gene therapy } \\
\hline Drug & Specie & Experimental model & Ischemic time & Effect \\
\hline Bag-1 (adenoviral transfer) & Rat & Liver transplantation & $24 \mathrm{~h}$ & $\begin{array}{l}\downarrow \text { TNF } \alpha, \downarrow \text { neutrophil infiltration, } \\
\downarrow \text { microcirculatory disturbances }\end{array}$ \\
\hline Bcl-2 gene (adenoviral transfer) & Rat & Liver transplantation & $16 \mathrm{~h}$ & $\downarrow$ Apoptosis \\
\hline $\mathrm{Cu} / \mathrm{Zn}$-SOD gene (adenoviral transfer) & Rat & Liver transplantation & $24 \mathrm{~h}$ & $\downarrow$ Oxidative stress \\
\hline HO-1 gene (adenoviral transfer) & Rat & Liver transplantation & $4 \mathrm{~h}$ & $\begin{array}{l}\downarrow \text { Macrophage infiltration, } \downarrow \\
\text { apoptosis }\end{array}$ \\
\hline IL-13 (adenoviral transfer) & Rat & Liver transplantation & $24 \mathrm{~h}$ & $\begin{array}{l}\downarrow \text { Proinflammatory cytokines, } \downarrow \\
\text { liver neutrophil recruitment }\end{array}$ \\
\hline Adiponectin (siRNA) & Rat & Warm ischemia & $1 \mathrm{~h}$ & $\downarrow$ Oxidative stress \\
\hline ASMase (siRNA) & Mice & $\begin{array}{l}\text { Warm ischemia }+ \\
\text { hepatectomy }\end{array}$ & $90 \mathrm{~min}$ & $\downarrow$ Ceramide, $\downarrow$ apoptosis \\
\hline Caspase 3 (siRNA) & Mice & Warm ischemia & $90 \mathrm{~min}$ & $\downarrow$ Apoptosis \\
\hline Caspase 8 (siRNA) & Mice & Warm ischemia & $90 \mathrm{~min}$ & $\downarrow$ Apoptosis \\
\hline SOD gene (adenoviral transfer) & Rat & Warm ischemia & $1 \mathrm{~h}$ & $\downarrow$ Oxidative stress \\
\hline IL-13 (adenoviral transfer) & Rat & Warm ischemia & $30 \mathrm{~min}$ & $\begin{array}{l}\downarrow \text { Proinflammatory cytokine, } \downarrow \\
\text { neutrophil recruitment }\end{array}$ \\
\hline
\end{tabular}

for apoptosis [111]. Although the benefits of preoxygenated PFC have been reported on liver preservation, their effects on reperfusion injury were not evaluated in that study. In fact, the possibility that preoxygenated PFC exacerbates the reactive oxygen species during reperfusion should not be discarded. In fact, previous studies indicate that the use of gaseous oxygen, applied to the livers during the storage period via the caval vein was only effective in improving hepatic viability upon reperfusion when antioxidants were added to the UW rinse solution [117].

7.3. Gene Therapy. Advances in molecular biology have provided new opportunities to reduce liver $\mathrm{I} / \mathrm{R}$ injury using gene therapy $[13,14,31,80,118-120]$ (see Table 3). However, the experimental data indicate that there are a number of problems inherent in gene therapy, such as vector toxicity, difficulties in increasing transfection efficiencies and protein expression at the appropriate time and site, and the problem of obtaining adequate mutants (in the case of $\mathrm{NF} \kappa \mathrm{B}$ ) due to the controversy regarding $\mathrm{NF} \kappa \mathrm{B}$ activation $[121,122]$. Although nonviral vectors (such as naked DNA and liposomes) are likely to present fewer toxic or immunological problems, they suffer from inefficient gene transfer [122]. In addition, LT is an emergency procedure in most cases, which leaves very little time to pretreat the donor with genetic approaches.

7.4. Surgical Strategies. The response of hepatocyte to ischemia never ceases to surprise. In fact, contrary to what might be expected, the induction of consecutive periods of ischemia in the liver does not induce an additive effect in terms of hepatocyte lesions. IP based on brief periods of ischemia followed by a short interval of reperfusion prior to a prolonged ischemic stress protects the liver against
I/R injury by regulating different cell types and multiple mechanisms such as energy metabolism, microcirculatory disturbances, leukocyte adhesion, KC activation, proinflammatory cytokine release, oxidative stress, apoptosis, and necrosis $[13,80]$ (Table 4 ). This is an advantage in relation with the use of drugs that exerts its action on a specific mechanism.

The benefits of IP observed in experimental models of hepatic warm and cold ischemia $[80,123]$ prompted human trials of IP. To date, IP has been successfully applied in human liver resections in both steatotic and nonsteatotic livers. The effectiveness of IP in hepatic surgery was first reported by Clavien et al. in 2003 [124], preliminary clinical studies have reported the benefits of IP in LT $[125,126]$, and additional randomized clinical studies are necessary to confirm whether this surgical strategy can be commonly used in clinical liver surgery.

\section{Conclusion and Perspectives}

From the data obtained in experimental models of hepatic $I / R$, we can state that $I / R$ injury is a multifaceted and intriguing phenomenon that probably cannot be reduced to a single pathway. The increasing use of marginal donors in major liver surgery and the fact that these organs are more susceptible to ischemia highlight the need for further research directed at the mechanisms of I/R injury. However, the mechanisms by which metabolic changes due to age or steatosis affect $\mathrm{I} / \mathrm{R}$ injury and subsequently influence protective strategies are poorly understood. Whether liver machine perfusion will find its way into widespread clinical application remains uncertain. Machine perfusion has been criticized for its complicated logistics (e.g., portability) and for possibly damaging the organ and vital structures such as 


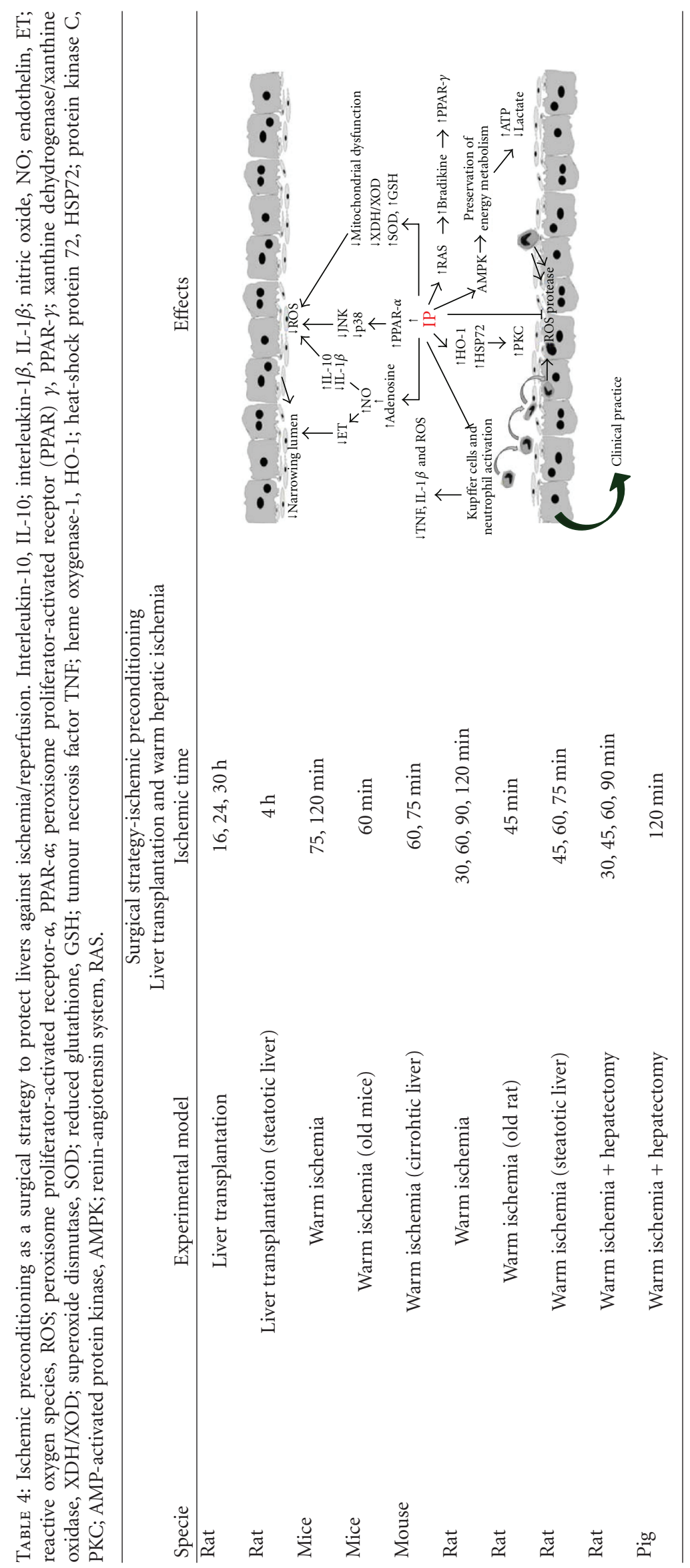


the endothelium. On the contrary, NMP fulfils all ideal organ preservation criteria by avoiding hypoxia and hypothermia. Responses to the strategies aimed at reducing hepatic I/R injury might depend on the surgical procedure and type of liver. Whether the pharmacological approaches presented in this review can be translated into treatments for human disease remains unknown, but further research is required to optimize the treatments. Surgical strategies such as IP affect multiple aspects of IR injury, whereas pharmacological approaches often affect only a few mediators and might have systemic side effects. Only a full appraisal of the mechanisms involved in hepatic I/R using experimental models will permit the design of new protective strategies in clinical liver surgery.

\section{Acknowledgments}

The author thank Bioscience Writers for revising the English text. M. Mendes-Braz is in receipt of a fellowship from CAPES Foundation, Ministry of Education of Brazilia, Brasília. MB. Jiménez-Castro is in receipt of a fellowship from SETH Foundation (Sociedad Española de Transplante Hepatico) Spain. This research was supported by the Ministerio de Ciencia e Innovación (project Grant BFU2009-07410) Madrid, Spain; the ACC1Ó (project Grant VALTEC08-20033) Barcelona, Spain.

\section{References}

[1] H. Jaeschke, "Mechanisms of reperfusion injury after warm ischemia of the liver," Journal of Hepatobiliary \& Pancreatic Surgery, vol. 5, no. 4, pp. 402-408, 1998.

[2] N. C. Teoh and G. C. Farrell, "Hepatic ischemia reperfusion injury: pathogenic mechanisms and basis for hepatoprotection," Journal of Gastroenterology and Hepatology, vol. 18, no. 8, pp. 891-902, 2003.

[3] H. Jaeschke, "Molecular mechanisms of hepatic ischemiareperfusion injury and preconditioning," American Journal of Physiology, Gastrointestinal and Liver Physiology, vol. 284, no. 1, pp. G15-G26, 2003.

[4] A. Serafin, J. Rosello-Catafau, N. Prats, C. Xaus, E. Gelpi, and C. Peralta, "Ischemic preconditioning increases the tolerance of fatty liver to hepatic ischemia-reperfusion injury in the rat," American Journal of Pathology, vol. 161, no. 2, pp. 587601, 2002.

[5] P. A. Clavien, P. R. C. Harvey, and S. M. Strasberg, "Preservation and reperfusion injuries in liver allografts: an overview and synthesis of current studies," Transplantation, vol. 53, no. 5, pp. 957-978, 1992.

[6] C. Huguet, A. Gavelli, P. A. Chieco et al., "Liver ischemia for hepatic resection: where is the limit?" Surgery, vol. 111, no. 3, pp. 251-259, 1992.

[7] R. W. Busuttil and K. Tanaka, "The utility of marginal donors in liver transplantation," Liver Transplantation, vol. 9, no. 7, pp. 651-663, 2003.

[8] R. J. Ploeg, A. M. D’Alessandro, S. J. Knechtle et al., "Risk factors for primary dysfunction after liver transplantationa multivariate analysis," Transplantation, vol. 55, no. 4, pp. 807-813, 1993.

[9] K. E. Behrns, G. G. Tsiotos, N. F. DeSouza, M. K. Krishna, J. Ludwig, and D. M. Nagorney, "Hepatic steatosis as a potential risk factor for major hepatic resection," Journal of Gastrointestinal Surgery, vol. 2, no. 3, pp. 292-298, 1998.

[10] M. Massip-salcedo, J. Roselló-Catafau, J. Prieto, M. A. Avíla, and C. Peralta, "The response of the hepatocyte to ischemia," Liver International, vol. 27, no. 1, pp. 6-16, 2007.

[11] C. Peralta, D. Closa, G. Hotter, E. Gelpí, N. Prats, and J. Roselló-Catafau, "Liver ischemic preconditioning is mediated by the inhibitory action of nitric oxide on endothelin," Biochemical and Biophysical Research Communications, vol. 229, no. 1, pp. 264-270, 1996.

[12] A. B. Lentsch, A. Kato, H. Yoshidome, K. M. McMasters, and M. J. Edwards, "Inflammatory mechanisms and therapeutic strategies for warm hepatic ischemia/reperfusion injury," Hepatology, vol. 32, no. 2, pp. 169-173, 2000.

[13] A. Casillas-Ramírez, I. B. Mosbah, F. Ramalho, J. RosellóCatafau, and C. Peralta, "Past and future approaches to ischemia-reperfusion lesion associated with liver transplantation," Life Sciences, vol. 79, no. 20, pp. 1881-1894, 2006.

[14] N. Selzner, H. Rudiger, R. Graf, and P. A. Clavien, "Protective strategies against ischemic injury of the liver," Gastroenterology, vol. 125, no. 3, pp. 917-936, 2003.

[15] E. E. Abdo, J. E. M. Cunha, P. Deluca, A. M. M. Coelho, T. Bacchella, and M. C. C. Machado, "Protective effect of n2-mercaptopropionylglycine on rats and dogs liver during ischemia/reperfusion process," Arquivos De Gastroenterologia, vol. 40, no. 3, pp. 177-180, 2003.

[16] A. M. Yahanda, C. N. Paidas, and M. G. Clemens, "Susceptibility of hepatic microcirculation to reperfusion injury: a comparison of adult and suckling rats," Journal of Pediatric Surgery, vol. 25, no. 2, pp. 208-213, 1990.

[17] A. Gasbarrini, G. Addolorato, C. Di Campli et al., "Gender affects reperfusion injury in rat liver," Digestive Diseases and Sciences, vol. 46, no. 6, pp. 1305-1312, 2001.

[18] M. Varela-Rey, N. Embade, U. Ariz, S. C. Lu, J. M. Mato, and M. L. Martínez-Chantar, "Non-alcoholic steatohepatitis and animal models: understanding the human disease," International Journal of Biochemistry and Cell Biology, vol. 41, no. 5, pp. 969-976, 2009.

[19] M. Vidal, “Traitement chirurgical des ascites," La Presse Médicale, vol. 11, pp. 747-749, 1903.

[20] A. Blakemore and J. Lord, "The technic of using vitallium tubes in establishing portacaval shunts for portal hypertension," Annals of Surgery, vol. 122, no. 4, pp. 449-475, 1945.

[21] W. E. Burnett, G. P. Rosemond, J. K. Weston, and R. R. Tyson, "Studies of hepatic response to changes in blood supply," Surgical Forum, pp. 147-153, 1951.

[22] D. Bernstein and S. Cheiker, "Simple technique for portocaval shunt in the rat," Journal of Applied Physiology, vol. 14, no. 3, pp. 467-470, 1959.

[23] H. U. Spiegel, C. Bremer, C. Boin, and M. Langer, "Reduction of hepatic reperfusion injury by indomethacin-mediated vasoconstriction: a rat model with temporary splenocaval shunt," Journal of Investigative Surgery, vol. 8, no. 5, pp. 363369, 1995.

[24] D. Uhlmann, B. Armann, G. Gaebel et al., "Endothelin a receptor blockade reduces hepatic ischemia/reperfusion injury after warm ischemia in a pig model," Journal of Gastrointestinal Surgery, vol. 7, no. 3, pp. 331-339, 2003.

[25] S. Bengmark, B. Börjesson, T. Olin, S. Sakuma, and J. Vosmic, "Subcutaneous transposition of the spleen-an experimental study in the rat," Scandinavian Journal of Gastroenterology, Supplement, vol. 7, pp. 175-179, 1970. 
[26] C. G. Meredith and D. N. Wade, "A model of portal-systemic shunting in the rat," Clinical and Experimental Pharmacology \& Physiology, vol. 8, pp. 651-652, 1981.

[27] S. Omokawa, Y. Arai, H. Saito et al., "A simple experimental model of total hepatectomy, hepatic ischemia and extrahepatic portal obstruction in rats using splenic transposition," Japanese Journal of Surgery, vol. 21, no. 1, pp. 50-56, 1991.

[28] S. Suzuki, S. Nakamura, T. Sakaguchi et al., "Pathophysiological appraisal of a rat model of total hepatic ischemia with an extracorporeal portosystemic shunt," Journal of Surgical Research, vol. 80, no. 1, pp. 22-27, 1998.

[29] H. Yamauchi, I. Baca, and U. Mittmann, "Postischemic liver damage in rats: effect of some therapeutic interventions on survival rate," Tohoku Journal of Experimental Medicine, vol. 138, no. 1, pp. 63-70, 1982.

[30] P. O. Hasselgren, E. Jennische, J. Fornander, and A. Hellman, "No beneficial effect of atp-mgcl2 on impaired transmembrane potential and protein synthesis in liver ischemia," Acta Chirurgica Scandinavica, vol. 148, no. 7, pp. 601-607, 1982.

[31] M. Massip-Salcedo, M. A. Zaouali, S. Padrissa-Altés et al., "Activation of peroxisome proliferator-activated receptor- $\alpha$ inhibits the injurious effects of adiponectin in rat steatotic liver undergoing ischemia-reperfusion," Hepatology, vol. 47, no. 2, pp. 461-472, 2008.

[32] A. Casillas-Ramirez, M. Amine-Zaouali, M. Massip-Salcedo et al., "Inhibition of angiotensin ii action protects rat steatotic livers against ischemia-reperfusion injury," Critical Care Medicine, vol. 36, no. 4, pp. 1256-1266, 2008.

[33] C. Peralta, R. Bartrons, L. Riera et al., "Hepatic preconditioning preserves energy metabolism during sustained ischemia," American Journal of Physiology, Gastrointestinal and Liver Physiology, vol. 279, no. 1, pp. G163-G171, 2000.

[34] F. S. Ramalho, I. Alfany-Fernandez, A. Casillas-Ramirez et al., "Are angiotensin ii receptor antagonists useful strategies in steatotic and nonsteatotic livers in conditions of partial hepatectomy under ischemia-reperfusion?" Journal of Pharmacology and Experimental Therapeutics, vol. 329, no. 1, pp. 130-140, 2009.

[35] M. Selzner, C. A. Camargo, and P. A. Clavien, "Ischemia impairs liver regeneration after major tissue loss in rodents: protective effects of interleukin-6," Hepatology, vol. 30, no. 2, pp. 469-475, 1999.

[36] H. U. Spiegel and D. Palmes, "Surgical techniques of orthotopic rat liver transplantation," Journal of Investigative Surgery, vol. 11, no. 2, pp. 83-96, 1998.

[37] T. Hori, J. H. Nguyen, X. Zhao et al., "Comprehensive and innovative techniques for liver transplantation in rats: a surgical guide," World Journal of Gastroenterology, vol. 16, no. 25, pp. 3120-3132, 2010.

[38] M. A. Aller, M. Mendez, M. P. Nava, L. Lopez, J. L. A. Arias, and J. Arias, "The value of microsurgery in liver research," Liver International, vol. 29, no. 8, pp. 1132-1140, 2009.

[39] S. Lee, A. C. Charters, J. G. Chandler, and M. J. Orloff, "A technique for orthotopic liver transplantation in the rat," Transplantation, vol. 16, no. 6, pp. 664-669, 1973.

[40] S. Lee, A. C. Charters, and M. J. Orloff, "Simplified technic for orthotopic liver transplantation in the rat," American Journal of Surgery, vol. 130, no. 1, pp. 38-40, 1975.

[41] N. Kamada and R. Y. Calne, "Orthotopic liver transplantation in the rat. technique using cuff for portal vein anastomosis and biliary drainage," Transplantation, vol. 28, no. 1, pp. 4750, 1979.
[42] J. P. Hölzen, D. Palmes, M. Langer, and H. U. Spiegel, "Microsurgical training curriculum for learning kidney and liver transplantation in the rat," Microsurgery, vol. 25, no. 8, pp. 614-623, 2005.

[43] Y. Ma, G. D. Wang, Z. Y. Guo, Z. G. Guo, X. S. He, and G. $\mathrm{H}$. Chen, "Surgical techniques of arterialized orthotopic liver transplantation in rats," Chinese Medical Journal, vol. 120, no. 21, pp. 1914-1917, 2007.

[44] G. Oldani, M. Maestri, A. Gaspari et al., "A novel technique for rat liver transplantation using quick linker system: a preliminary result," Journal of Surgical Research, vol. 149, no. 2, pp. 303-309, 2008.

[45] H. Urakami, Y. Abe, and M. B. Grisham, "Role of reactive metabolites of oxygen and nitrogen in partial liver transplantation: lessons learned from reduced-size liver ischaemia and reperfusion injury," Clinical and Experimental Pharmacology and Physiology, vol. 34, no. 9, pp. 912-919, 2007.

[46] R. Franco-Gou, C. Peralta, M. Massip-Salcedo, C. Xaus, A. Serafín, and J. Roselló-Catafau, "Protection of reduced-size liver for transplantation," American Journal of Transplantation, vol. 4, no. 9, pp. 1408-1420, 2004.

[47] T. Omura, N. L. Ascher, and J. C. Emond, "Fifty-percent partial liver transplantation in the rat," Transplantation, vol. 62, no. 2, pp. 292-293, 1996.

[48] O. De Rougemont, K. Lehmann, and P. A. Clavien, "Preconditioning, organ preservation, and postconditioning to prevent ischemia-reperfusion injury to the liver," Liver Transplantation, vol. 15, no. 10, pp. 1172-1182, 2009.

[49] T. Vogel, J. G. Brockmann, and P. J. Friend, "Ex-vivo normothermic liver perfusion: an update," Current Opinion in Organ Transplantation, vol. 15, no. 2, pp. 167-172, 2010.

[50] D. Monbaliu and J. Brassil, "Machine perfusion of the liver: past, present and future," Current Opinion in Organ Transplantation, vol. 15, no. 2, pp. 160-166, 2010.

[51] M. R. Schön, O. Kollmar, S. Wolf et al., "Liver transplantation after organ preservation with normothermic extracorporeal perfusion," Annals of Surgery, vol. 233, no. 1, pp. 114-123, 2001.

[52] C. Fondevila, A. J. Hessheimer, A. Ruiz et al., "Liver transplant using donors after unexpected cardiac death: novel preservation protocol and acceptance criteria," American Journal of Transplantation, vol. 7, no. 7, pp. 1849-1855, 2007.

[53] J. C. García-Valdecasas and C. Fondevila, "In-vivo normothermic recirculation: an update," Current Opinion in Organ Transplantation, vol. 15, no. 2, pp. 173-176, 2010.

[54] B. H. Pienaar, S. L. Lindell, T. Van Gulik, J. H. Southard, and F. O. Belzer, "Seventy-two-hour preservation of the canine liver by machine perfusion," Transplantation, vol. 49, no. 2, pp. 258-260, 1990.

[55] K. Vekemans, Q. Liu, J. Brassil, M. Komuta, J. Pirenne, and D. Monbaliu, "Influence of flow and addition of oxygen during porcine liver hypothermic machine perfusion," Transplantation Proceedings, vol. 39, no. 8, pp. 2647-2651, 2007.

[56] M. Vairetti, A. Ferrigno, F. Carlucci et al., "Subnormothermic machine perfusion protects steatotic livers against preservation injury: a potential for donor pool increase?" Liver Transplantation, vol. 15, no. 1, pp. 20-29, 2009.

[57] B. Gonzalez-Flecha, J. C. Cutrin, and A. Boveris, "Time course and mechanism of oxidative stress and tissue damage in rat liver subjected to in vivo ischemia-reperfusion," Journal of Clinical Investigation, vol. 91, no. 2, pp. 456-464, 1993. 
[58] E. Klar, M. Angelescu, C. Zapletal, T. Kraus, M. Bredt, and C. Herfarth, "Definition of maximum cold ischemia time without reduction of graft quality in clinical liver transplantation," Transplantation Proceedings, vol. 30, no. 7, pp. 3683-3685, 1998.

[59] L. Fernandez, N. Heredia, L. Grande et al., "Preconditioning protects liver and lung damage in rat liver transplantation: role of xanthine/xanthine oxidase," Hepatology, vol. 36, no. 3, pp. 562-572, 2002.

[60] H. Jaeschke and J. R. Mitchell, "Mitochondria and xanthine oxidase both generate reactive oxygen species in isolated perfused rat liver after hypoxic injury," Biochemical and Biophysical Research Communications, vol. 160, no. 1, pp. 140-147, 1989.

[61] H. Hayashi, I. H. Chaudry, M. G. Clemens, and A. E. Baue, "Hepatic ischemia models for determining the effects of atpmgcl2 treatment," Journal of Surgical Research, vol. 40, no. 2, pp. 167-175, 1986.

[62] I. H. Chaudry, M. G. Clemens, M. Ohkawa, S. Schleck, and A. E. Baue, "Restoration of hepatocellular function and blood flow following hepatic ischemia with atp- $\mathrm{MgCl}_{2}$," Advances in Shock Research, vol. 8, pp. 177-186, 1982.

[63] M. Stadler, V. Nuyens, L. Seidel, A. Albert, and J. G. Boogaerts, "Effect of nutritional status on oxidative stress in an ex vivo perfused rat liver," Anesthesiology, vol. 103, no. 5, pp. 978-986, 2005.

[64] R. Cywes, P. D. Greig, J. R. Sanabria et al., "Effect of intraportal glucose infusion on hepatic glycogen content and degradation, and outcome of liver transplantation," Annals of Surgery, vol. 216, no. 3, pp. 235-247, 1992.

[65] M. Domenicali, G. Vendemiale, G. Serviddio et al., "Oxidative injury in rat fatty liver exposed to ischemia-reperfusion is modulated by nutritional status," Digestive and Liver Disease, vol. 37, no. 9, pp. 689-697, 2005.

[66] H. N. Sankary, A. Chong, P. Foster et al., "Inactivation of kupffer cells after prolonged donor fasting improves viability of transplanted hepatic allografts," Hepatology, vol. 22, no. 4 I, pp. 1236-1242, 1995.

[67] T. Okaya, J. Blanchard, R. Schuster et al., "Age-dependent responses to hepatic ischemia/reperfusion injury," Shock, vol. 24, no. 5, pp. 421-427, 2005.

[68] A. Gasbarrini, P. Pasini, B. Nardo et al., "Chemiluminescent real time imaging of post-ischemic oxygen free radicals formation in livers isolated from young and old rats," Free Radical Biology and Medicine, vol. 24, no. 2, pp. 211-216, 1998.

[69] S. Ijaz, W. Yang, M. C. Winslet, and A. M. Seifalian, "Impairment of hepatic microcirculation in fatty liver," Microcirculation, vol. 10, no. 6, pp. 447-456, 2003.

[70] M. Selzner, H. A. RüDiger, D. Sindram, J. Madden, and P. A. Clavien, "Mechanisms of ischemic injury are different in the steatotic and normal rat liver," Hepatology, vol. 32, no. 6, pp. 1280-1288, 2000.

[71] P. Caraceni, M. Domenicali, G. Vendemiale et al., "The reduced tolerance of rat fatty liver to ischemia reperfusion is associated with mitochondrial oxidative injury," Journal of Surgical Research, vol. 124, no. 2, pp. 160-168, 2005.

[72] L. Fernández, E. Carrasco-Chaumel, A. Serafín et al., "Is ischemic preconditioning a useful strategy in steatotic liver transplantation?" American Journal of Transplantation, vol. 4, no. 6, pp. 888-899, 2004.
[73] I. Ben Mosbah, I. Alfany-Fernández, C. Martel et al., "Endoplasmic reticulum stress inhibition protects steatotic and non-steatotic livers in partial hepatectomy under ischemiareperfusion," Cell Death and Disease, vol. 1, no. 7, article no. e52, 2010.

[74] I. Alfany-Fernandez, A. Casillas-Ramirez, M. BintanelMorcillo et al., "Therapeutic targets in liver transplantation: angiotensin ii in nonsteatotic grafts and angiotensin-(1-7) in steatotic grafts," American Journal of Transplantation, vol. 9, no. 3, pp. 439-451, 2009.

[75] A. Casillas-Ramírez, I. Alfany-Fernández, M. MassipSalcedo et al., "Retinol-binding protein 4 and peroxisome proliferator-activated receptor- $\gamma$ in steatotic liver transplantation," Journal of Pharmacology and Experimental Therapeutics, vol. 338, no. 1, pp. 143-153, 2011.

[76] A. Serafin, J. Rosello-Catafau, N. Prats, E. Gelpi, J. Rodes, and C. Peralta, "Ischemic preconditioning affects interleukin release in fatty livers of rats undergoing ischemia/reperfusion," Hepatology, vol. 39, no. 3, pp. 688698, 2004.

[77] W. Gao, H. D. Connor, J. J. Lemasters, R. P. Mason, and R. G. Thurman, "Primary nonfunction of fatty livers produced by alcohol is associated with a new, antioxidant-insensitive free radical species," Transplantation, vol. 59, no. 5, pp. 674-679, 1995.

[78] S. Yamada, T. Iida, T. Tabata et al., "Alcoholic fatty liver differentially induces a neutrophil-chemokine and hepatic necrosis after ischemia-reperfusion in rat," Hepatology, vol. 32, no. 2, pp. 278-288, 2000.

[79] C. Peralta, R. Bartrons, A. Serafin, C. Blazquez, M. Guzman, N. Prats et al., "Adenosine monophosphate-activated protein kinase mediates the protective effects of ischemic preconditioning on hepatic ischemia-reperfusion injury in the rat," Hepatology, vol. 34, no. 2, pp. 278-288, 2000.

[80] R. Bahde and H. U. Spiegel, "Hepatic ischaemia-reperfusion injury from bench to bedside," British Journal of Surgery, vol. 97, no. 10, pp. 1461-1475, 2010.

[81] T. Shin, S. Kuboki, N. Huber et al., "Activation of peroxisome proliferator-activated receptor- $\gamma$ during hepatic ischemia is age-dependent," Journal of Surgical Research, vol. 147, no. 2, pp. 200-205, 2008.

[82] T. Akahori, M. Sho, K. Hamada et al., "Importance of peroxisome proliferator-activated receptor- $\gamma$ in hepatic ischemia/reperfusion injury in mice," Journal of Hepatology, vol. 47, no. 6, pp. 784-792, 2007.

[83] D. Sindram, V. Kohli, J. F. Madden, and P. A. Clavien, "Calpain inhibition prevents sinusoidal endothelial, cell apoptosis in the cold ischemic rat liver," Transplantation, vol. 68, no. 1, pp. 136-140, 1999.

[84] Y. H. Tian, T. Schäfer, A. Sckell, and M. K. Schilling, "Adenosine deaminase inhibition attenuates reperfusion low flow and improves graft survival after rat liver transplantation," Transplantation, vol. 69, no. 11, pp. 2277-2281, 2000.

[85] M. Arai, R. G. Thurman, and J. J. Lemasters, "Contribution of adenosine a 2 receptors and cyclic adenosine monophosphate to protective ischemic preconditioning of sinusoidal endothelial cells against storage/reperfusion injury in rat livers," Hepatology, vol. 32, no. 2, pp. 297-302, 2000.

[86] F. Amersi, X. D. Shen, C. Moore et al., "Fibronectin- $\alpha 4 \beta 1$ integrin-mediated blockade protects genetically fat zucker rat livers from ischemia/reperfusion injury," American Journal of Pathology, vol. 162, no. 4, pp. 1229-1239, 2003. 
[87] T. G. Lehmann, T. A. Koeppel, M. Kirschfink et al., "Complement inhibition by soluble complement receptor type 1 improves microcirculation after rat liver transplantation," Transplantation, vol. 66, no. 6, pp. 717-722, 1998.

[88] I. Yokoyama, T. Kobayashi, M. Negita et al., "Liberation of vasoactive substances and its prevention with thromboxane a2 synthase inhibitor in pig liver transplantation," Transplant International, vol. 9, no. 1, pp. 76-81, 1996.

[89] H. Reynaert, A. Geerts, and J. Henrion, "Review article: the treatment of non-alcoholic steatohepatitis with thiazolidinediones," Alimentary Pharmacology and Therapeutics, vol. 22, no. 10, pp. 897-905, 2005.

[90] S. Hassan-Khabbar, C. H. Cottart, D. Wendum et al., "Postischemic treatment by trans-resveratrol in rat liver ischemia-reperfusion: a possible strategy in liver surgery," Liver Transplantation, vol. 14, no. 4, pp. 451-459, 2008.

[91] R. Schmidt, "Hepatic organ protection: from basic science to clinical practice," World Journal of Gastroenterology, vol. 16, no. 48, pp. 6044-6045, 2010.

[92] M. M. R. Polyak, B. O. Arrington, S. Kapur, W. T. Stubenbord, and M. Kinkhaswala, "Glutathione supplementation during cold ischemia does not confer early functional advantage in renal transplantation," Transplantation, vol. 70, no. 1, pp. 202-205, 2000.

[93] C. Peralta, L. Fernandez, J. Panes, N. Prats, M. Sans, J. Pique et al., "Preconditioning protects against systemic disorders associated with hepatic ischemia-reperfusion through blockade of tumor necrosis factor-induced P-selectin upregulation in the rat," Hepatology, vol. 33, no. 1, pp. 100-113, 2001.

[94] E. Carrasco-Chaumel, J. Roselló-Catafau, R. Bartrons et al., "Adenosine monophosphate-activated protein kinase and nitric oxide in rat steatotic liver transplantation," Journal of Hepatology, vol. 43, no. 6, pp. 997-1000, 2005.

[95] K. D. Chavin, R. N. Fiorini, S. Shafizadeh et al., "Fatty acid synthase blockade protects steatotic livers from warm ischemia reperfusion injury and transplantation," American Journal of Transplantation, vol. 4, no. 9, pp. 1440-1447, 2004.

[96] K. D. Chavin, S. Yang, H. Z. Lin et al., "Obesity induces expression of uncoupling protein-2 in hepatocytes and promotes liver atp depletion," Journal of Biological Chemistry, vol. 274, no. 9, pp. 5692-5700, 1999.

[97] K. Yonezawa, R. H. Tolba, A. Wetter, Y. Yamamoto, Y. Yamaoka, and T. Minor, "L-carnitine could not improve hepatic warm ischemia-reperfusion injury despite ameliorated blood flow," Journal of Surgical Research, vol. 125, no. 1, pp. 16-22, 2005.

[98] F. Hong, S. Radaeva, H. N. Pan, Z. Tian, R. Veech, and B. Gao, "Interleukin 6 alleviates hepatic steatosis and ischemia/reperfusion injury in mice with fatty liver disease," Hepatology, vol. 40, no. 4, pp. 933-941, 2004.

[99] E. J. Pesonen, N. Linder, K. O. Raivio et al., "Circulating xanthine oxidase and neutrophil activation during human liver transplantation," Gastroenterology, vol. 114, no. 5, pp. 1009-1015, 1998.

[100] C. D. Anderson, G. Upadhya, K. D. Conzen et al., "Endoplasmic reticulum stress is a mediator of posttransplant injury in severely steatotic liver allografts," Liver Transplantation, vol. 17, no. 2, pp. 189-200, 2011.

[101] T. Maeda, N. Murase, V. Subbotin et al., "Analogs of cyclic nucleotides in rat liver preservation," Transplantation, vol. 66, no. 7, pp. 844-851, 1998.

[102] A. B. Quintana, H. L. Lenzi, L. L. Almada et al., "Effect of s-nitrosoglutathione (gsno) added to the university of wisconsin solution (UW): ii) functional response to cold preservation/reperfusion of rat liver," Annals of Hepatology, vol. 1, no. 4, pp. 183-191, 2002.

[103] X. L. Li, K. Man, K. T. Ng, C. K. Sun, C. M. Lo, and S. T. Fan, "The influence of phosphatidylinositol 3-kinase/akt pathway on the ischemic injury during rat liver graft preservation," American Journal of Transplantation, vol. 5, no. 6, pp. 12641275, 2005.

[104] A. M. El-Gibaly, C. Scheuer, M. D. Menger, and B. Vollmar, "Improvement of rat liver graft quality by pifithrin- $\alpha$ mediated inhibition of hepatocyte necrapoptosis," Hepatology, vol. 39, no. 6, pp. 1553-1562, 2004.

[105] S. Natori, M. Selzner, K. L. Valentino et al., "Apoptosis of sinusoidal endothelial cells occurs during liver preservation injury by a caspase-dependent mechanism," Transplantation, vol. 68, no. 1, pp. 89-96, 1999.

[106] S. Ambiru, K. Uryuhara, S. Talpe et al., "Improved survival of orthotopic liver allograft in swine by addition of trophic factors to university of wisconsin solution," Transplantation, vol. 77, no. 2, pp. 302-319, 2004.

[107] K. Vajdová, R. Graf, and P. A. Clavien, "Atp-supplies in the cold-preserved liver: a long-neglected factor of organ viability," Hepatology, vol. 36, no. 6, pp. 1543-1552, 2002.

[108] S. Matsumoto and Y. Kuroda, "Perfluorocarbon for organ preservation before transplantation," Transplantation, vol. 74, no. 12, pp. 1804-1809, 2002.

[109] Y. Fujino, "Two-layer cold storage method for pancreas and islet cell transplantation," World Journal of Gastroenterology, vol. 16, no. 26, pp. 3235-3238, 2010.

[110] J. Lakey, T. Tsujimura, A. Shapiro, and Y. Kuroda, "Preservation of the human pancreas before islet isolation usging a two-layer (UW solution-perfluorochemical) cold storage method," Tranplantation, vol. 74, no. 12, pp. 1809-1811, 2002.

[111] D. Bezinover, S. Ramamoorthy, T. Uemura et al., "Use of a third-generation perfluorocarbon for preservation of rat DCD liver grafts," submitted to Journal of Surgical Research.

[112] N. Kamada, R. Y. Calne, D. G. D. Wight, and J. G. Lines, "Orthotopic rat liver transplantation after long-term preservation by continuous perfusion with fluorocarbon emulsion," Transplantation, vol. 30, no. 1, pp. 43-48, 1980.

[113] T. Tamaki, N. Kamada, D. G. Wight, and D. E. Pegg, "Successful 48-hour preservation of the rat liver by continuous hypothermic perfusion with haemaccel-isotonic citrate solution," Transplantation, vol. 43, no. 4, pp. 468-471, 1987.

[114] H. Shiki, Y. Ku, Y. Kuroda, and Y. Saito, "The effect of oxygen supply in continuos cold perfusion of the rat liver using perfluorochemical emulsion-parenchymal and nonparenchymal cell injuries evaluated with trypan blue perfusion/fixation techniques," Nihon Geka Gakkai Zasshi, vol. 94, no. 9, pp. 1033-1042, 1993.

[115] E. Klar, T. Kraus, P. Reuter et al., "Oxygenated perfusion for liver preservation: a perfluorodecalin-uw emulsion is not feasible," Transplantation Proceedings, vol. 30, no. 7, pp. 3707-3710, 1998.

[116] S. A. Hosgood and M. L. Nicholson, "The role of perfluorocarbon in organ preservation,” Transplantation, vol. 89, no. 10, pp. 1169-1175, 2010.

[117] T. Minor and M. Kötting, "Gaseous oxygen for hypothermic preservation of predamaged liver grafts: fuel to cellular homeostasis or radical tissue alteration?" Cryobiology, vol. 40, no. 2, pp. 182-186, 2000.

[118] C. Fan, R. M. Zwacka, and J. F. Engelhardt, "Therapeutic approaches for ischemia/reperfusion injury in the liver," 
Journal of Molecular Medicine, vol. 77, no. 8, pp. 577-592, 1999.

[119] L. Llacuna, M. Marí, C. Garcia-Ruiz, J. C. Fernandez-Checa, and A. Morales, "Critical role of acidic sphingomyelinase in murine hepatic ischemia-reperfusion injury," Hepatology, vol. 44, no. 3, pp. 561-572, 2006.

[120] J. L. Contreras, M. Vilatoba, C. Eckstein, G. Bilbao, J. Anthony Thompson, and D. E. Eckhoff, "Caspase8 and caspase-3 small interfering rna decreases ische$\mathrm{mia} /$ reperfusion injury to the liver in mice," Surgery, vol. 136, no. 2, pp. 390-400, 2004.

[121] M. L. Chaisson, J. T. Brooling, W. Ladiges, S. Tsai, and N. Fausto, "Hepatocyte-specific inhibition of nf- $\kappa \mathrm{b}$ leads to apoptosis after tnf treatment, but not after partial hepatectomy," Journal of Clinical Investigation, vol. 110, no. 2, pp. 193-202, 2002.

[122] N. Somia and I. M. Verma, "Gene therapy: trials and tribulations," Nature Reviews Genetics, vol. 1, no. 2, pp. 9199, 2000.

[123] K. K. Desai, G. S. Dikdan, A. Shareef, and B. Koneru, "Ischemic preconditioning of the liver: a few perspectives from the bench to bedside translation," Liver Transplantation, vol. 14, no. 11, pp. 1569-1577, 2008.

[124] P. A. Clavien, M. Selzner, H. A. Rudiger, R. Graft, Z. Kadry, V. Rousson et al., "A prospective randomized study in 100 consecutive patients undergoing major liver resection with versus without ischemic preconditioning," Annals of Surgery, vol. 238, no. 6, pp. 843-850, 2003.

[125] D. Azoulay, M. Del Gaudio, P. Andreani et al., "Effects of 10 minutes of ischemic preconditioning of the cadaveric liver on the graft's preservation and function: the ying and the yang," Annals of Surgery, vol. 242, no. 1, pp. 133-139, 2005.

[126] W. Jassem, S. V. Fuggle, L. Cerundolo, N. D. Heaton, and M. Rela, "Ischemic preconditioning of cadaver donor livers protects allografts following transplantation," Transplantation, vol. 81, no. 2, pp. 169-174, 2006. 


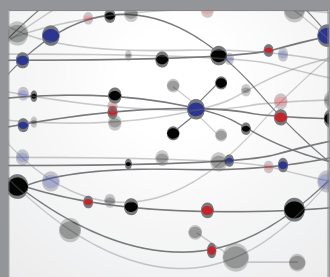

The Scientific World Journal
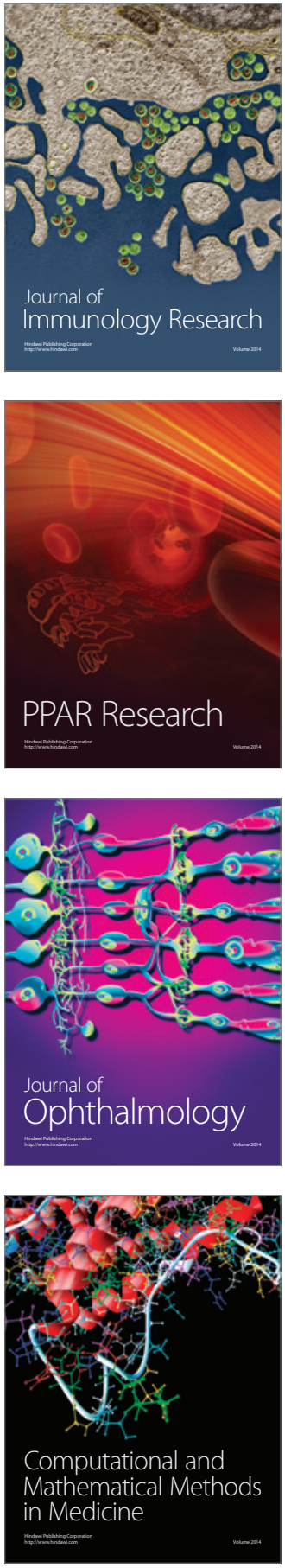

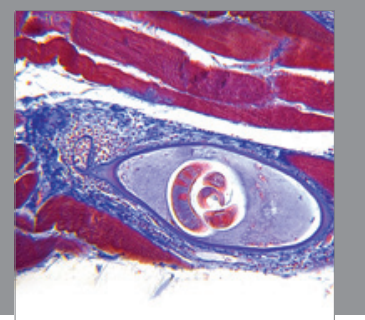

Gastroenterology

Research and Practice
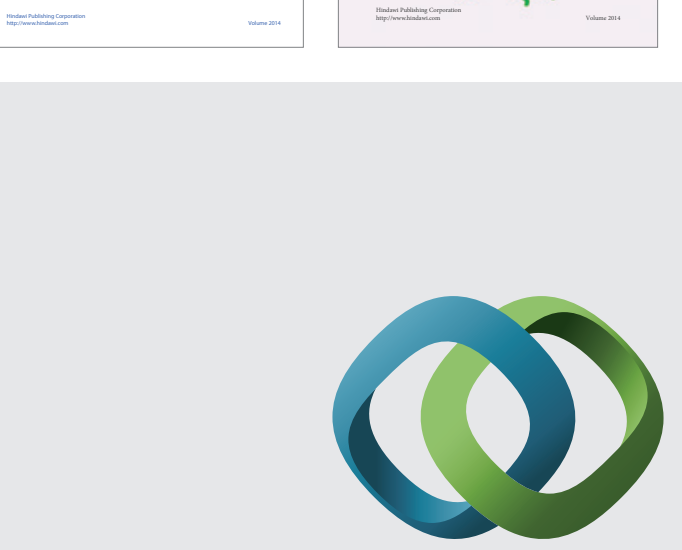

\section{Hindawi}

Submit your manuscripts at

http://www.hindawi.com
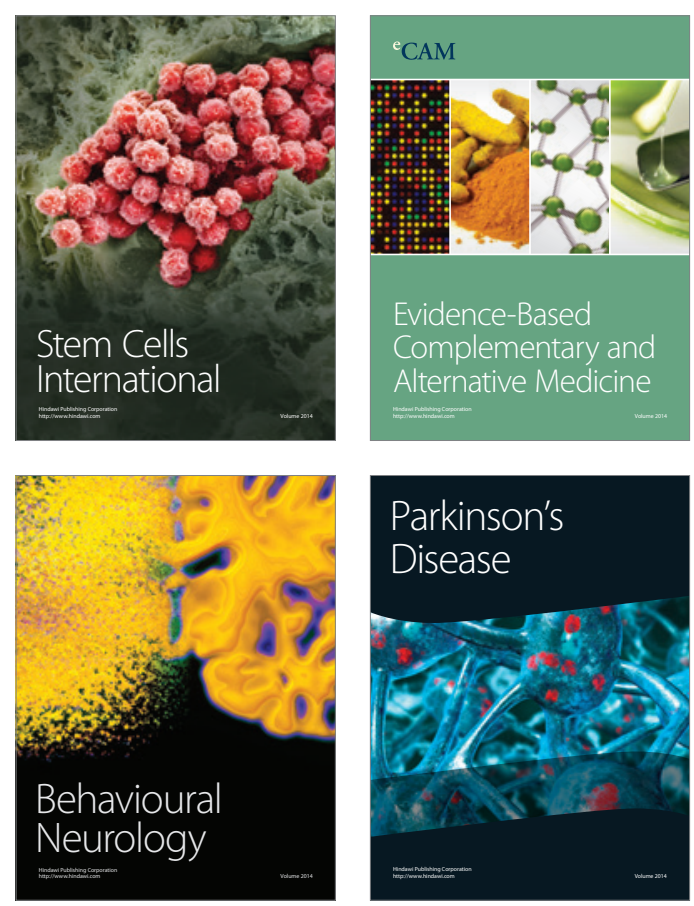

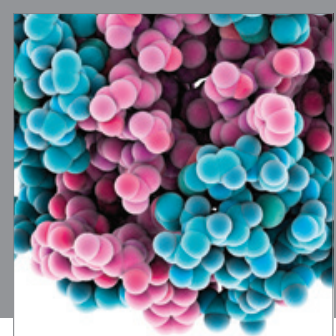

Journal of
Diabetes Research

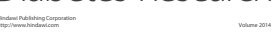

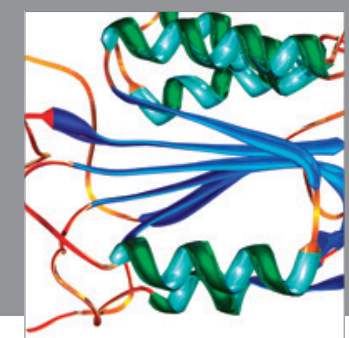

Disease Markers
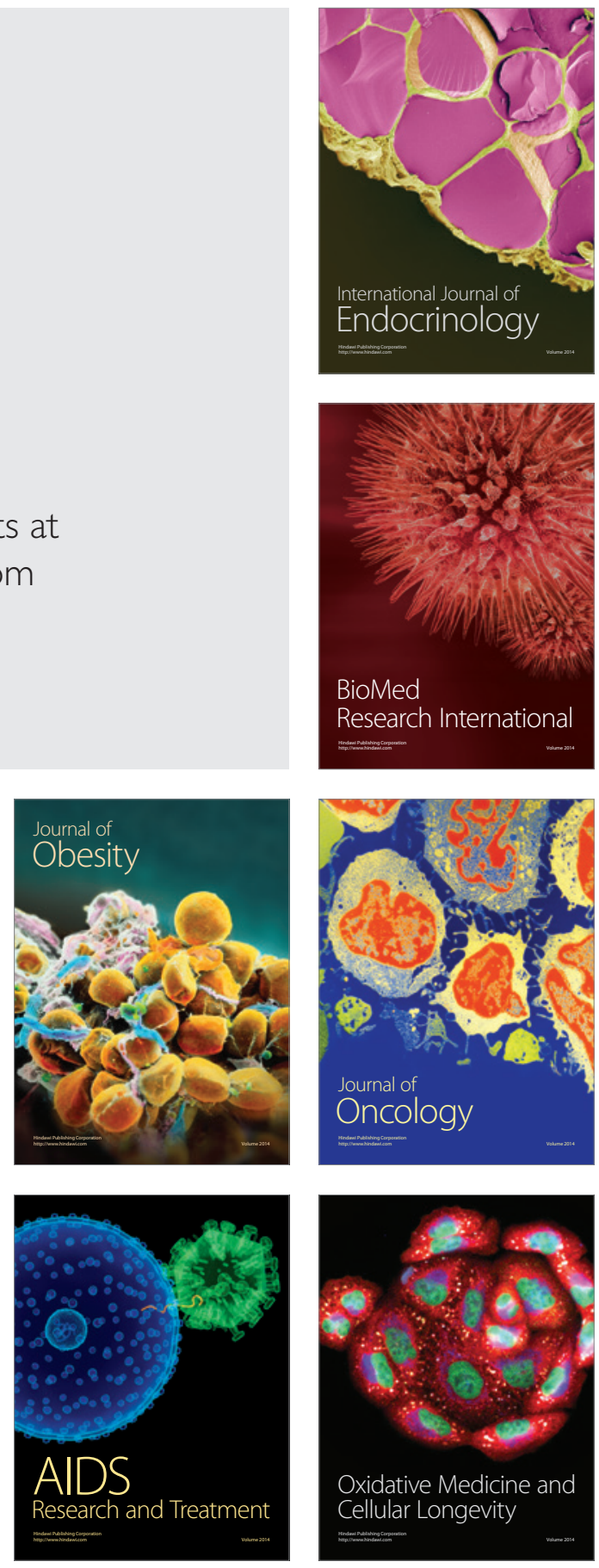